UDC 546.[62+284]: 552.524: 613.2

DOI: $10.21668 /$ health.risk/2020.1.16.eng

\title{
NANOCLAYS IN FOOD PRODUCTS: BENEFITS AND POSSIBLE RISKS (LITERATURE REVIEW)
}

\author{
I.V. Gmoshinski ${ }^{1}$, O.V. Bagryantseva ${ }^{1,2}$, O.V. Arnautov ${ }^{3}$, S.A. Khotimchenko ${ }^{1,2}$ \\ ${ }^{1}$ Federal Research Center for Nutrition, Biotechnology and Food Safety, 2/14 Ust'inskiy lane, Moscow, 109240, \\ Russian Federation \\ ${ }^{2}$ I.M. Sechenov First Moscow State Medical University, Bld. 2, 2 Bolshaya Pirogovskaya Str., Moscow, 119991, \\ Russian Federation \\ ${ }^{3}$ Eurasian Economic Commission, Bld.1/2, 2 Letnikovskaya St., Moscow, 115114, Russian Federation
}

Nanoclays (NC) are aluminosilicates that consist of layers (nano-plates) being 1-2 nanometers thick and having a diameter over $1 \mu \mathrm{m}$, nanotubes, and nano-disks. Due to such structure and their ion-exchange and sorption properties as well as gas permeability NC are widely used in industries, agriculture, and medicine. Gas-barrier composite packages are made from hydrophobic NC modified with cation-active surface-active substances. A person can be orally exposed to NC due to their migration from packages into food products and drinks, when NC are applied in medicine as enteric sorbents and antibacterial preparations, they can be introduced with food additives and residual quantities of technological auxiliaries as well as in case when food products and agricultural raw materials are accidentally contaminated with clays. Multiple research works dwell on experiments with NC performed with model systems in vitro when NC turned out to be cytotoxic for various cell types, and it was more apparent for hydrophobic NC than for their non-modified analogues. Minimum effective $N C$ dose varied from 0.001 to $1 \mathrm{mg} / \mathrm{ml}$ in various in vitro tests. In vitro research on NC toxicity yielded somewhat contradictory results. Though $\mathrm{NC}$ didn't seem to have apparent acute toxicity (IV hazard category, $L D_{50}>5,000 \mathrm{mg} / \mathrm{kg}$ ), results obtained via sub-acute and chronic experiments with their duration being up to 196 days and single clinical observations revealed a number of both toxic and non-toxic effects. Organic NC modifiers were highly toxic in vitro. Besides, NC produce anti-microbe effects and it may result in dysbiotic disorders when they are introduced orally. Model experiments revealed that NC and their organic modifiers could possibly migrate from packages into food products. NC are able to free silicon and aluminum that are partly biologically available. A contribution made by NC that are contained in packages into overall exposure to toxic aluminum should be examined profoundly given an adverse situation caused by clay minerals being introduced into a human body as components contained in food additives. Assessment of aluminum consumption with food rations in Russia and several foreign countries revealed it was necessary to exclude potassium and calcium aluminosilicates, bentonite, and kaolin (E555, E556, E558, and E559) from the list of additives that are permitted for use in food industry.

Key words: nanoclays, aluminum, food additive, exposure, biological availability, toxicity, intestinal microbiocenose, risks.

Introduction. At present food products are manufactured with wide use of food additives and technological auxiliaries; they are usually packed into innovative packaging. It creates certain functional and economic advantages that justify using these food additives and technological auxiliaries provided that food products still remain safe for health of this and future generations. In this relation technologists and hygienists are paying greater attention to clay minerals applied in food manufacturing including various non-modified and chemically modified nanoclays (NCs). Aluminum occurs in most clay minerals; this

(C) Gmoshinski I.V., Bagryantseva O.V., Arnautov O.V., Khotimchenko S.A., 2020

Ivan V. Gmoshinski - Doctor of Biological Sciences, leading researcher at the Laboratory for Food Toxicity and Nanotechnologies Safety Assessment (e-mail: gmosh@ion.ru; tel.: +7 (495) 698-53-71; ORCID: https://orcid.org/0000-0002-3671-6508).

Olga V. Bagryantseva - Doctor of Medical Sciences, Professor (Republic of Kazakhstan), leading researcher at the Laboratory for Food Toxicity andNanotechnologies Safety Assessment (e-mail: bagryantseva@ion.ru; tel.: +7 (495) 698-54-05; ORCID: https://orcid.org/0000-0003-3174-2675).

Oleg V. Arnautov - assistant member of the Board (Minister) for industry and agro-industrial complex of the Eurasian economic Commission (e-mail: arnautov@eecommission.org; tel.: +7 (985) 787-91-25; ORCID: https://orcid.org/0000-0003-3309-0308).

Sergey A. Khotimchenko - Doctor of Medical Sciences, Professor, Head of the Laboratory for Food Toxicity and Nanotechnologies Safety Assessment (e-mail: hotimchenko@ion.ru; tel.: +7 (495) 698-54-05; ORCID: https://orcid.org/0000-0002-5340-9649). 
metal is known to produce overall toxic and neurotoxic effects. So it is vital to have a closer look at risks caused by this element migrating into edible components of food products [1]. Besides, there are certain issues related to hypothetic toxic effects produced by clays as nanomaterials and occurring due to small sizes and peculiar physical and chemical properties of particles they are made of (so called "nano-toxicity") [2, 3]. And finally, a specific issue is hygienic assessment of synthetic organic modifiers that are applied in producing certain NCs.

In the present work we have analyzed and generalized data on NCs application, effects they produce on biological systems including a human body and microorganisms, as well as data on potential risks caused by NCs application in food manufacturing. Our research technique was searching, selecting, and analyzing literature sources (articles published in revised scientific journals, theses, and monographs, as well as reports issued by international organizations) using open databases including PubMed, Scopus, Google Scholar and RSCI; a period selected for the research was 1993-2019.

Clays classification and structure. Clay minerals are widely spread in the upper lithosphere, soils, and bottom sediments; they oc- curred due to long-term physical-chemical and biotic transformation of igneous volcanic rocks [4]. There are such varieties of clays as sedimentary rock as bentonite, kaolin, etc.; apart from clay minerals, they contain significant admixtures of quartz, cristobalite, calcite (chalk and marble), rutile, and other minerals. Clay minerals are divided into aluminosilicates and silicates (complex silic acid salts) as per their structure. The former are the most widely spread among clay minerals; their classification is given as a diagram in Figure 1 [5].

Bearing technological properties in mind, phyllosilicates made from layered aluminosilicates structures are the most interesting, especially smectites in which these layers are comparatively weakly bonded to each other and quite mobile. This peculiarity determines physical and chemical properties of smectites, namely their strong hydrophilic nature, ability to swell in water, non-linear rheological characteristics (thixotropy) and great adsorption capability to various molecules and ions. Montmorrilonite (MMT) is the most widely spread smectite which can be found in natural bentonite clays. Its chemical structure is shown in Figure 2a. MMT is made of layers (plates) with their diameter, as a rule, being equal to $1-10 \mu \mathrm{m}$ and their thickness varying

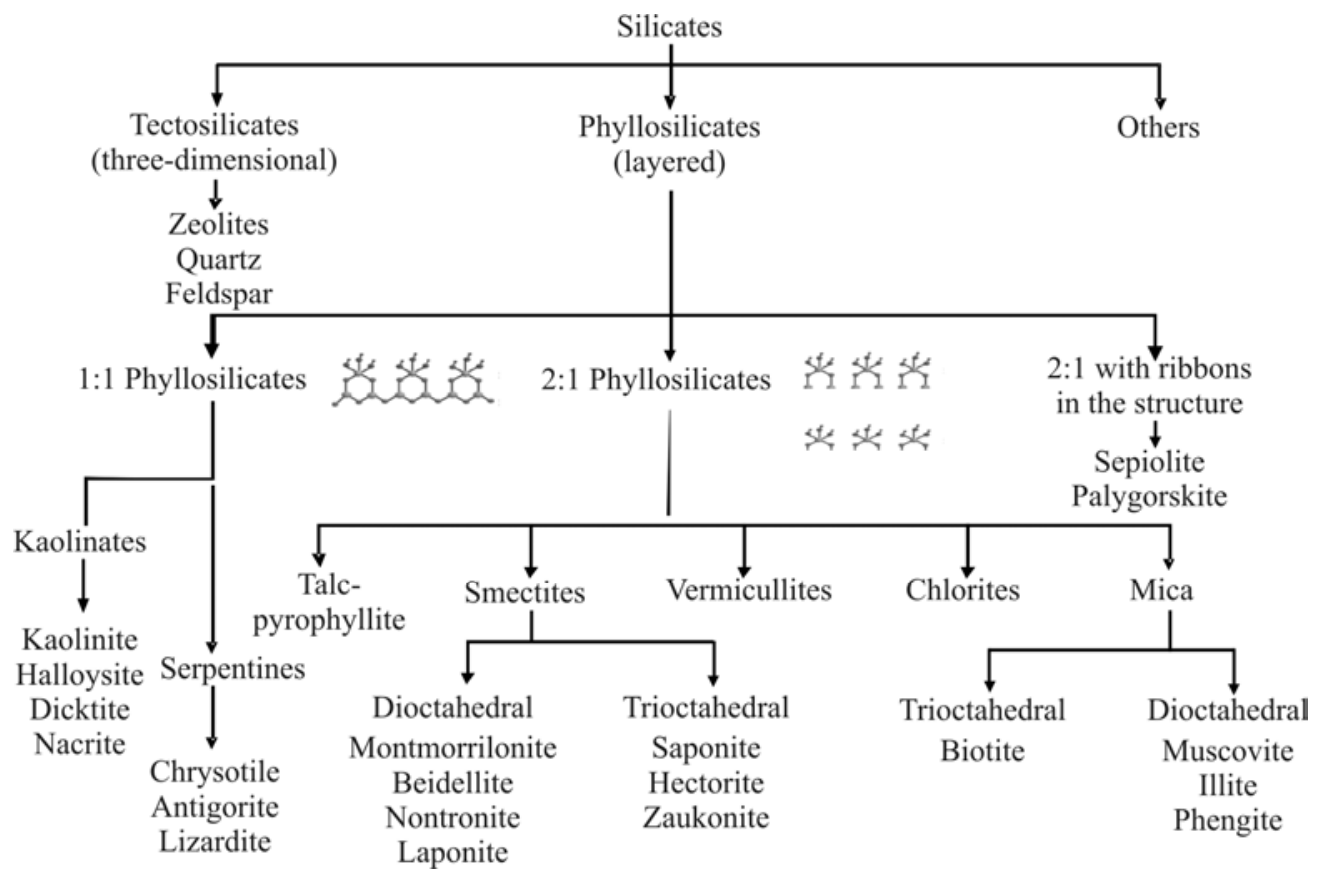

Figure 1. Silicates classification (as per data taken from [5]) 

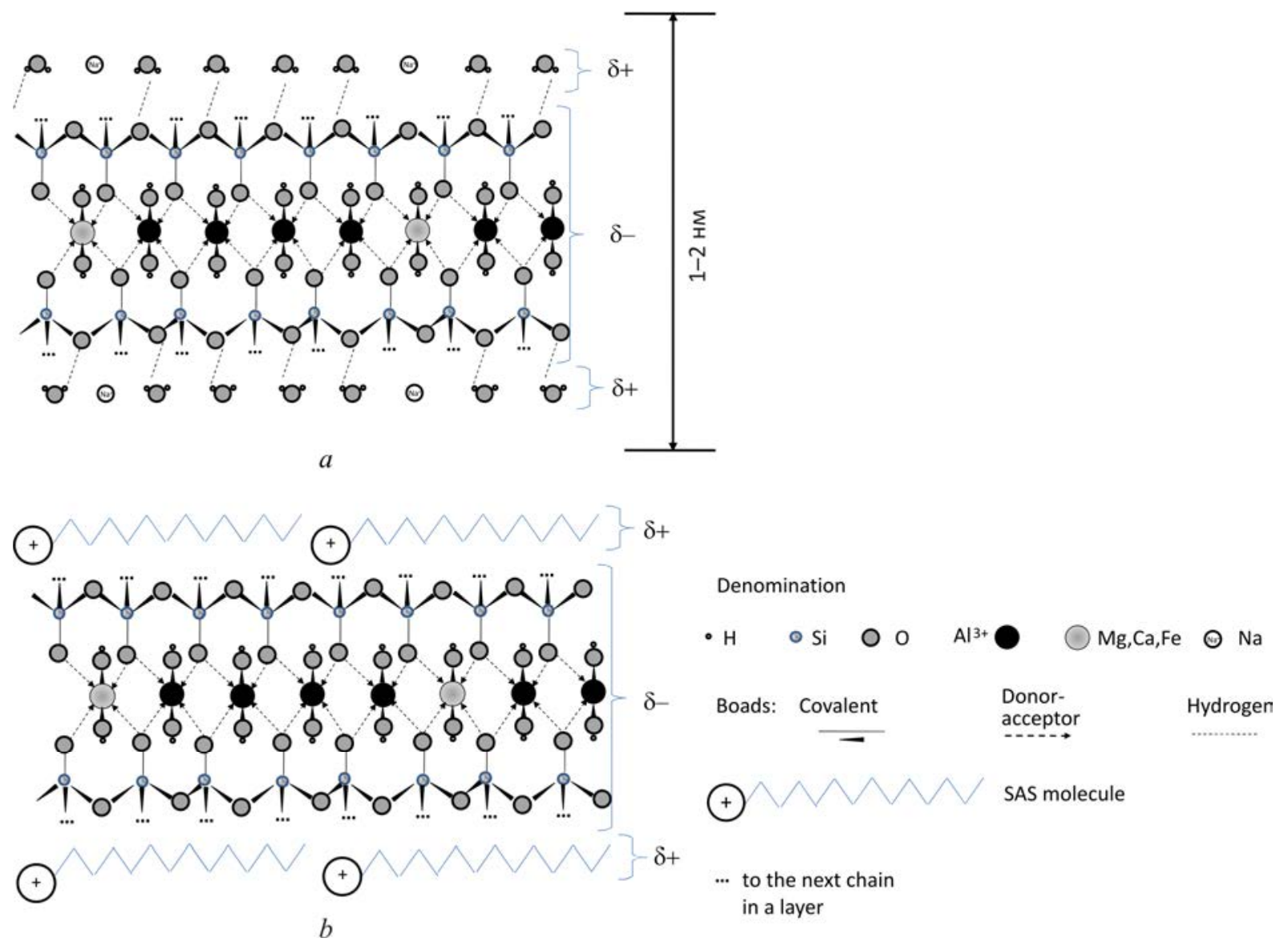

Figure 2. Chemical structure of montmorrilonite nanoclay $(a)$ and its organically modified form $(b)$

within 1-2 $\mathrm{nm}$ depending on medium properties and as per data obtained with different measuring techniques. A MMT plate is a three-layer structure consisting of two sheets made of conjugated silica-oxygen tetrahedrons and a sheet made of aluminum ions between them; all the sheets are octahedral-coordinated with oxygen atoms in silicate tetrahedrons and hydroxyl ions. An outer layer of each plate consists of water molecules held by hydrogen bonds. Interplanar spacing between MMT layers is significantly greater than a layer thickness and is equal to approximately $7 \mathrm{~nm}$ in dry MMT $[6,7]$.

Some $\mathrm{Al}^{3+}$ ions in MMT are able to undergo isomorphous substitution and be replaced with an uncertain number of bivalent cations $\left(\mathrm{Ca}^{2+}, \mathrm{Mg}^{2+}, \mathrm{Fe}^{2+}\right)$; due to the process, a three-layer structure overall becomes negatively charged. This charge is compensated for with electrostatic binding within solvate shell of a plate that contains one-valent cations (usually $\mathrm{Na}^{+}$). These cations can be compara- tively easily exchanged for other positively charged particles and it determines MMT having cation-exchanging properties. Its empiric gross-formula can be given as $\left(\mathrm{M}_{\mathrm{x}}^{+} \cdot \mathrm{nH}_{2} \mathrm{O}\right)$ $\left.\cdot\left[\mathrm{Al}_{2-\mathrm{x}} \mathrm{Z}_{\mathrm{x}}\right) \mathrm{Si}_{4} \mathrm{O}_{10}(\mathrm{OH})_{2}\right]$, where $\mathrm{M}$ is a onevalent cation (sodium), $\mathrm{Z}$ is bivalent cation (magnesium, calcium, or iron), $x<0.5$. MMT extracted from natural bentonite, as a rule, contains insignificant admixtures of quartz sand and mica and can also contain certain toxic elements in trace quantities, for example, $\mathrm{Pb}, \mathrm{Cd}, \mathrm{Be}, \mathrm{Ba}, \mathrm{Sr}, \mathrm{Ni}$ and others.

Technological processing (making the material hydrophobic) involves sodium in MMT being replaced with ions of cationactive surface-active substances (SAS) which are aliphatic amines or quaternary ammonium bases; that is, substances with such composition as $\mathrm{R}_{1} \mathrm{R}_{2} \mathrm{R}_{3} \mathrm{CH}_{3} \mathrm{~N}^{+} \mathrm{Hal}^{-}$, where $\mathrm{R}_{\mathrm{i}}$ are aliphatic (from $\mathrm{C} 1$ to $\mathrm{C} 16$ ) or aromatic residues or hydrogen, and $\mathrm{Hal}^{-}$is chlorine or bromine anion (Figure 2b) [7-9]. SAS molecules create new bonds in interplanar space in MMT and 
displace water from it thereby replacing weak hydrogen bonds between layers with even weaker hydrophobic interactions; it results in spontaneous MMT splitting into separate plates and an organically modified NC is created $[7,10]$. Similar splitting is possible also with native watered MMT; however, it involves intensive outer mechanic exposure (ultrasound).

Hydrophobic organically modified NCs are basic raw materials applied in manufacturing nanocomposites with organic polymers which are used in packing and packages for food products [5].

There are some other clay minerals that are applied in food manufacturing and therefore should be given attention. One of them is kaolinite, a phyllosilicate with its structure close to MMT but the difference is that its structure has only two layers instead of three, one layer is silicon oxide and the other is aluminum oxide. Potassium prevails as an outer cation in kaolinite as opposed to MMT where this role belongs to sodium. Steric strains in the structure of kaolinite plates make them bend cylinder-like and the extreme case here is a nanotube formation. Another mineral, so called halloysite, is made of such aluminosilicate nanotubes. As opposed to carbon nanotubes, halloysite nanotubes are not closed; they are composed of kaolinite layers folded into rolls (Figure 3). A typical diameter of such nanotubes amounts to $20-50 \mathrm{~nm}$ and their length exceeds $1 \mu \mathrm{m}$. Another phyllosilicate is laponite that is close to MMT in its chemical structure but is made of nanoparticles (nanodisks) with a rather small diameter (it is usually $25-30 \mathrm{~nm}$ ) and $1 \mathrm{~nm}$ thick; it is prone to swelling and thixotropic gels formation.

Other clay minerals that are given in Figure 1 are applied in food manufacturing in rather insignificant quantities and have low practical importance.
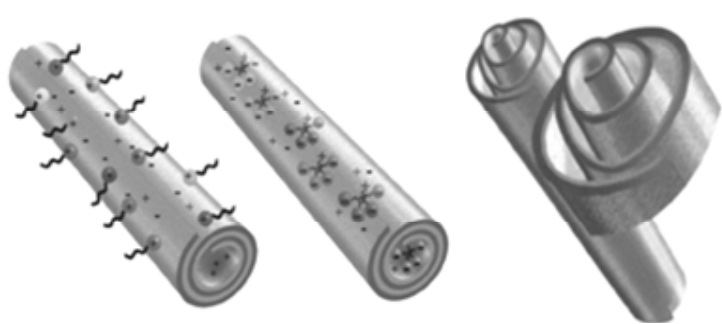

Figure 3. Structure of halloysite nanotubes
There are data in literature on probable practical application of so called "anionic" clays that are artificial layered mineral materials; they are usually created with other nonmetal element participating in their structure instead of silicon (usually carbon) or with chloride anion [11]. Any issues related to biological properties of those artificial materials might have not discussed in the present work.

How clays are applied in food manufacturing. MMT and some other phyllosilicates are widely used in various industries. There are data on more than 100 different areas where clays can be applied [5, 12].

NCs have high specific surface area and ion-exchange properties; due to that their adsorption capacity is also great and it provides an opportunity to intercalate organic molecules between their layers. Organically modified NCs are easily built into volumes of hydrophobic organic polymers thus creating planar structures (nanocomposites) [13]. A most significant property of clay nanocomposites is that NC plates are impermeable for gas molecules (oxygen or carbon dioxide) as well as for water; due to it gas or water molecules have to overcome a much longer path in their diffusion through a polymer [14] (Figure 4). Apart from this barrier function, nanocomposites are usually more solid and rigid, have greater thermal stability and resistance to swelling [15-18]. On the other hand, there are developments that allow obtaining clay nanocomposites with natural biopolymers (proteins or polysaccharides) that are able to degrade biologically and therefore are environmentally "friendly" $[19,20]$. Biologically degradable nanocomposites with antimicrobial properties were obtained via combining vegetative polysaccharides, NCs and natural essential oils [21,22]. There are data on creating a biological nanocomposites based on montmorrilonite clay that had antioxidant properties and contained silibin, an extract of holy thistle [23]. Barrier properties typical for nanoclays are widely used in producing film packages and packing that are able to prevent packed products from drying up and oxidationinduced spoilage, as well as prevent carbonated drinks from degassing [16, 24, 25]. Nano- 

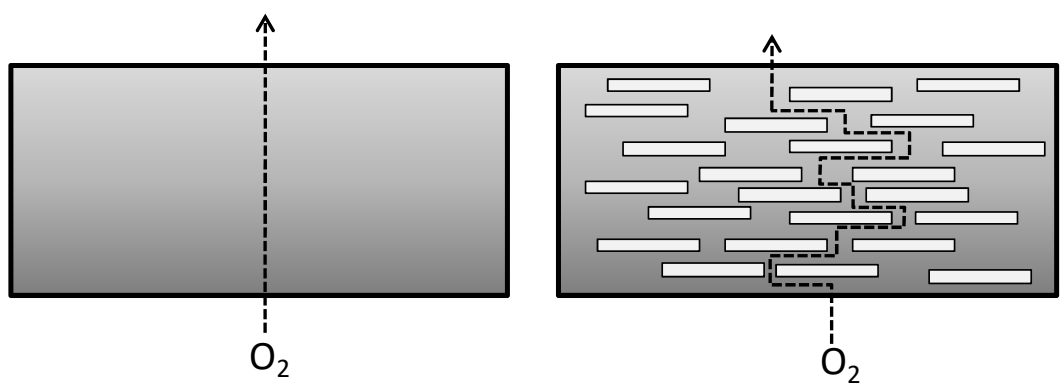

Figure 4. A scheme that explains gas-barrier properties of nanoclays composites

composites based on clay with nisin are considered to be a useful compromise when this preservative is applied to prevent food products from spoilage taking into account insignificant migration of nisin from the nanomaterial into a food product [26, 27].

Overall, an effect produced by NCs and their modified forms applied in packing materials is that food products become safer and their quality improves [28]. NCs are becoming more and more widely used in food products packages and packing and this promising trend is developing rapidly. As per data given in [29] a market of nanocomposites applied in food products packages and packing in the USA was equal to 4.13 billion $\$$ in 2008 and it grew to more than 7 billion $\$$ in 2014 . Claybased composites accounted for the biggest share in this market [30].

NCs can be also used as medication carriers as it was discussed in a review [31]. Akbari A.M. et al. revealed an opportunity to use montmorrilonite clay as vitamin $\mathrm{B}_{12}$ carrier [32].

Some other ways to apply clays in food manufacturing are, for example, their use as technological auxiliaries (filter media, adsorbents, or flocculants) in manufacturing vegetable oils, beer, or non-alcoholic drinks. Clays, especially in their nanoform, are efficiently applied in this sphere due to their great adsorption capability regarding various ions and polar organic molecules [33, 34]. We should note that technological auxiliaries should be completely removed from ready food products during a production process. As opposed to that, food additives based on aluminosilicate clays that act as carriers and anti-caking agents can persist in certain food products. The legislation existing in the RF and EAEU countries in 2019 allows using some aluminosilicates as additives to food; they are sodium, potassium, and calcium aluminosilicates (E554-E556), bentonite (E558), and kaolin (E559) ${ }^{1}$. Standardized contents of the said food additives (separately or in a combination) in spices and products tightly wrapped in foil should not exceed $30 \mathrm{~g} / \mathrm{kg}$; sugar powder, $15 \mathrm{~g} / \mathrm{kg}$; cheese and its substitutes, $10 \mathrm{~g} / \mathrm{kg}$; salt, $10 \mathrm{~g} / \mathrm{kg}$. Use of aluminosilicate food additives in producing pelleted food products and biologically active additives (BAA), as well as sugary confectionary excluding chocolates (for surface treatment) is regulated in accordance with technological standards accepted by a manufacturer (according to technological chats in quantities necessary to produced desirable technological effects).

Use of clay minerals (MMT or kaolinite) as additives to forage implies that these substances have certain enterosorbent properties; it allows efficient preventing fusariose-induced toxicosis and acidosis in animals and makes for less active hepatic transaminases and lower lactate and biogenic amines (histamine and spermine) contents in blood serum $[35,36]$.

We should also note that so called "edible" clays are actually used as nutrition components in certain regions. Some African and Asian tribes with their socioeconomic and cultural development being rather low tend to eat mineral substances occurring in soils (so called

${ }^{1}$ CU TR 029/2012. The Customs Union Technical Regulations "Requirements to safety of additives to food, flavoring agents, and technological auxiliaries" (last edited on 18.09.2014). Appendix 2. KODEKS: the electronic fund for legal and reference documentation. Available at: http://docs.cntd.ru/document/902359401 (14.02.2020). 
"pica" phenomenon) [37]. There is an opinion that it helps them obtain certain mineral substances in additional quantities as these substances (potassium, magnesium, and iron) are found in clays in a form that is partially biologically available [38]. Besides, clays have apparent enterosorbent properties and it can make for prevention of enteric infections and aflatoxicosis [39]. When bentonite was consumed with food, it helped people living in Ghana excrete aflatoxins and T2 toxin out of their bodies [40]. It is interesting to note that there are specially designed (and certified as being safe) traditional food products based on "edible" African clay that are sold in some African countries (Nigeria, Cameroon, Ghana, Togo, the SAR, and others) as well as in the USA and Western Europe [37]. As we can see from available literature sources, this phenomenon is almost absent in the RF and EAEU countries.

NCs toxicity for live organisms. Though it is apparent that all the above mentioned ways to apply NCs can produce truly favorable technological effects, probable toxic impacts exerted by both modified and non-modified NCs on people and environmental objects can cause potential risks [41].

Data obtained via experiments in vitro. Experiments in vitro that were usually performed on human and animal cells cultures applied as test objects (both primary cultures of standard cells and transformed ones) allow obtaining data on cytotoxic properties of nanomaterials such as NCs; screening of presumably the most toxic nanomaterials out of the examined group; and getting an insight into probable nanotoxicity mechanisms [5, 42].

The WHO document [4] contains a review of early research works (published in 1969-1996) in which their authors described various effects produced by particles of MMT, kaolinite, and other clays in in vitro systems.

Some research works revealed that native MMT turned out to be cytotoxic. Four types of aluminosilicates were toxic for the human umbilical vein endothelium (HUVE) under exposure in concentrations varying from 0.01 to $0.1 \mathrm{mg} / \mathrm{ml}$ that lasted for $6-24$ hours; toxicity given in descending order: MMT $>$ native ben- tonite $>$ kaolinite $>$ zeolite [43]. Kaolinite and zeolite induced a dose-dependent increase in fatty acids production and cell lysis. Two other cell lines, neuroblastoma N1E-115 and oligodendrocytes ROC, were resistant to effects produced by clays.

Non-modified MMT in a concentration equal to $1 \mathrm{ml} / \mathrm{mg}$ in a 24-hour exposure resulted in weaker survivability of ovary cells taken from a CHO hamster [44]. The same results were obtained for intestinal cells of INT-407 line [45]. Non-modified MMT, Cloisite Na trademark, didn't have any cytotoxic effects on transformed intestinal epithelium cells Caco-2 after 24-hour exposure in a concentration equal to $0.17 \mathrm{mg} / \mathrm{ml}$, didn't cause any DNA breaks in them according to comet assay and was not mutagenic for Salmonella spp. in Ames test [46]. As per data obtained by Gao et al. [47] kaolin turned out to be cytotoxic for a primary culture of rat's lung macrophages and its cytotoxicity was similar to that of quarts; however, it caused less significant damage to DNA. Along with nano-plates, some data were obtained for nanotubes of native clays. Verma et al. [48] applied transformed lung epithelium cells A549 in their experiment and revealed that tubular clay structures were less toxic than nano-plates. An issue related to interpreting these data is different chemistry of these nanomaterials; to be exact, nano-plates were MMTbased, and nanotubes, halloysite. It should be noted that, according to Vergaro et al [49], native halloysite nanotubes were cytotoxic for HeLa and MCF-7 cells in a concentration higher than $0.075 \mathrm{mg} / \mathrm{ml}$. On the other hand, Lai et al. [50] didn't reveal any toxic effects produced by halloysite nanotubes on intestinal epithelium cells in concentrations varying within $0-0.1 \mathrm{mg} / \mathrm{ml}$ range.

Rawat et al. [51] compared cytotoxic effects produced by the natural MMT and synthetic laponite on HEK (human embryo kidneys) cells and $\mathrm{SiHa}$ (uterine neck carcinoma) cells as well as on E.coli culture. They also showed that clay nano-disks (laponite) had more apparent cytotoxic and antimicrobial effects than long nano-plates (MMT).

When an organic modifier consisting of cation-active SAS is introduced into nanoclay 
in order to make it hydrophobic, it can lead to considerable changes in cytotoxicity of the nanomaterial. It is related to both changes in physical and chemical properties of NC itself (its hydrophobic properties, zeta-potential, and aggregative stability) and, presumably, effects produced by a modifier that migrates from $\mathrm{NC}$ into biological media. Thus, organically modified MMT Cloisite 30B, as opposed to its native precursor, was genotoxic for $\mathrm{Caco} 2$ cells and mutagenic for Salmonella sp. [46]. The same effects were produced by Cloisite 30B that was filtered through a $2-\mu \mathrm{m}$ thick membrane and didn't contain any clay; consequently, occurring effects were most likely due to a migrating modifier. Organically modified Cloisite 93A nanoclay was more cytotoxic than native MMT in a culture that contained transformed liver cells HepG2 after a 24-hour exposure [52].

An increase in cytotoxicity of organically modified NCs depended on a modifier and its essence. Thus, when a modifier was diethylbenzyldialkyl-ammonium based on fatty acids obtained from tallow, it resulted in greater toxicity of modified MMT for certain cell lines (Ramos, Burkitt lymphoma; A-549, lung adenocarcinoma; HCT116, colorectal carcinoma; SK-MEL 28, melanoma; HepG2, hepatocellular carcinoma; and HUVEC human umbilical veil endothelium) than when a modifier was dimethylalkyl-ammonium base [53]. Those data were well in line with cytotoxic effects produced by those modifiers themselves on the said cell lines. Concentration of $50 \%-$ inhibiting $\left(\mathrm{LC}_{50}\right)$ didecyldimethyl-ammonium saccharinate in a test with tetrazolium salts (MMT-test) was within $1.44-5.47 \mathrm{mM}$ range for certain lines of human cells [54]. Native MMT turned out to be less toxic than organically modified one (Cloisite 30B) in experiments performed on HepG-2 and Caco-2 cells $[55,56]$. Threshold toxic concentrations of two organically modified NCs varying in a modifier structure changed from 8 to $30 \mu \mathrm{g} / \mathrm{l}$. Modified NCs in concentrations higher than 30 $\mu \mathrm{kg} / 1$ caused DNA fragmentation in cells of both lines and depletion of reduced glutathione resources in HepG-2 cells. Effective concen- trations of various hydrophobic NC modifiers differed also according to data obtained from $[7,55-58]$.

When bentonite was "activated" by the treatment with sulfuric acid, it resulted in its higher cytotoxicity for human B-lymphoblasts $[59,60]$. The process, together with reduced ability of the cells to survive, also involved greater oxidants production and damage to DNA. Water extracts from clay didn't apparently have any genotoxic effects as it was revealed in those experiments.

On the other hand, there are data that certain modifications of nanoclays don't result in their increasing cytotoxicity. Thus, Han et al. [61] stated there was no damage done to membranes and no reduction in survivability of cells from 4 lines when they contacted organically modified calcium and magnesium phyllosilicates. Native and functionalized halloysite nanotubes had the same cytotoxicity for HeLa and MCF-7 cells in concentrations higher than $0.075 \mathrm{mg} / \mathrm{ml}$ [49].

There are relatively few assessments of cytotoxicity that NC composites might have in available literature. When MMT was built into oligo co-polymer of styrene with acrylonitrile, it resulted in its lower cytotoxicity [62]. The same authors revealed [63] that a composite that contained halloysite nanotubes with chitosan was not cytotoxic for fibroblasts from NIH3T3 line and was quite biologically compatible such as films made from pure chitosan. L-929 fibroblasts were more adhesive and grew better on chitosan without clay in comparison with chitosan that contained MMT in quantity from 1 to $8 \%$ [64].

Kevadiya et al. [65] stated that clay composites were able to act as reservoirs for cytotoxic medications, and their side toxic effects produced on normal cells could decrease whereas medications could be delivered to their destination more efficiently.

The fact that nanocomposites have different toxicity may result from quantities of NCs and organic modifiers that migrate from them. In particular, Cloisite $30 \mathrm{~B}$ nanoclay that contains quaternary ammonium base can be extracted from a biopolymer nanocomposite based on 
soya polysaccharide [66]. Cloisite $30 \mathrm{~B} \mathrm{NC}$ was cytotoxic for Hep 2, C26 and HTC cells in concentrations varying from 39.1 to $90.17 \mu \mathrm{kg} / \mathrm{l}$. Cloisite $30 \mathrm{~B}$ particles migrated from packing film into the liquid media in significant quantities. It was concluded that a nanocomposite with such structure could be applied for packing dry products only and it could protect them to a certain extent from bacterial contamination but not from mold fungi.

It is rather alarming that people may be exposed to aerosols occurring when packing wastes with NCs in their structure are burnt at combustion plants. Wagner A. et al. [67] performed their experiments on BEAS-2B cells of human lung epithelium and revealed that burning under $900{ }^{\circ} \mathrm{C}$ didn't exert any significant impacts on cytotoxicity of native MMT and drastically reduced cytotoxicity of organically modified Cloisite 30B nanoclay; it corresponded to relevant burning out of its organic component. The same authors performed similar experiments [68] to examine cytotoxicity of solid products occurring after burning of a polymer nanocomposite that contained three different organically modified nanoclays. They showed that combustion products that had powder-like or spongy structures with their particles size significantly exceeding $100 \mathrm{~nm}$ didn't produce any apparent cytotoxic effects in a concentration up to $0.3 \mathrm{mg} / \mathrm{ml}$. The authors made a conclusion that although any organically modified NC was more cytotoxic than native one its cytotoxicity went down considerably during packing materials combustion due to modifiers in its structure having been burnt out.

Data obtained via in vitro tests allow making assumptions as regards mechanisms of cytotoxic effects occurring in direct contacts between NC and cells. Thus, lysis occurred in HUVE cells after 24-hour exposure to MMT, bentonite, and kaolinite [43]. Short-term exposure (60 minutes) to MMT and bentonite resulted in complete lysis of neuronal cells [69]. Morphological changes appeared in HepG-2 and Caco-2 cells exposed for 24-48 hours to organically modified Cloisite $93 \mathrm{~A} \mathrm{NC}$ in a concentration varying from 0.05 to $1 \mathrm{mg} / \mathrm{ml}$; among those changes were damages to mitochondria, nucleus, and endoplasmic reticulum [55]. Degenerated mitochondria in HepG2 and Caco-2 cells exposed to organically modified NCs are consistent with data obtained via MTT-test performed on many cell types exposed to both modified and native halloysite nanotubes [44, 45, 49, 50, 52, 55-58, 63]. Fatty impurities in HepG-2 and Caco-2 cells cultivated with $\mathrm{C} 30 \mathrm{~B}$ present during cultivation indicate that lipid metabolism is violated [43]. All the above stated facts allow one to assume that a direct contact between non-modified MMT and different cell types results in damage to them with prevailing antioxidant stress caused by catalytic synthesis of free radicals at interphase borders whereas the basic factor that makes organically modified clays toxic is their organic component (a modifier) that produced membranetropic effects [5].

Therefore, as per data obtained from numerous research works, negative effects produced by NCs on different cells are undoubted. But it is impossible to determine whether significant these effects are in terms of toxic impacts produced by NCs on a human body without exact data on exposure scenarios, quantities in which nanomaterials migrate from package and packing into products and NCs ability to penetrate through biological barriers.

Data obtained via experiments in vivo. Research works on clay minerals toxicity performed in vivo are not so numerous as compared to data obtained via in vitro systems; available results are hardly comparable due to experimental models and tested objects being different form each other. A review on early data on clay mineral toxicity is given in works $[4,70]$.

Overall, exposure to clay materials can stimulate both toxic and non-toxic response. The latter can occur due to favorable effects produced by clays as enterosorbents as they are able to reduce burdens related to penetration of aflatoxins, heavy metals and microbe metabolites into a body; they produce antacidic effects; and serve as a source of essential microelements that can be consumed with them in certain additional quantities $[5,71,72]$. Most early 
works revealed that clays didn't induce overall toxic and histopatologic changes, both under single exposure in an acute experiment $[45,73$, 74] and in a sub-acute or chronic one lasting up to 196 days [75-78] performed on rodents. For example, Baek et al. [45] estimated $\mathrm{LD}_{50}$ of non-modified MMT for mice and it amounted to $41,000 \mathrm{mg} / \mathrm{kg}$ of body weight. Wiles et al. [79] stated that MMT was not toxic or produced negligible toxic effects on pregnant SpragueDawley female rats and they didn't reveal any embryotoxicity either. However, previously Patterson and Staszak (1977), cited as per [5] revealed certain reproductive toxicity as there was anemia in female rats and lower body weight of newborn offspring after exposure to kaolin in quantity amounting to $20 \%$ in the overall forage mass.

There have been few in vivo research works on clay minerals toxicity in the last 10 years. There was a suspicious case when cats got poisoned by bentonite after swallowing bentonitecontaining cat litter; they suffered from hypokaliemia and hypochromic anemia, lethargy and muscle weakness. Orally introduced bentonite resulted in lower calcium contents in bone tissue of goats. Bentonite didn't compensate for a decrease in calcium contents in shinbones of broilers with alimentary deficiency. A 3-year old girl who had been exposed to bentonite orally and rectally as a home-made medication suffered from severe hypokaliemia [40].

On the other hand, Maisanaba et al. [78] didn't reveal any increase in lipoperoxides, or changes in activity of superoxide dismutase (SOD), glutathione peroxidase (GPx), and glutathione-S-transferase (GST) in the liver or kidneys of rats after 40-day exposure to organically modified MMT; although, catalase became more active, and there was an increase in its protein contents and gene expression in the kidneys. EFSA [76] gives some data on chromosome aberrations revealed in rats that were exposed to bentonite for 15 days. However, Sharma et al. [80] didn't detect any breaks in DNA chains in cells or any inflammatory response in the large intestine, liver or kidneys of Wistar rats that had been twice exposed to organically modified Cloisite $30 \mathrm{~B}$ via a stomach tube in a dose $250-1,000 \mathrm{mg} / \mathrm{kg}$ of body weight. This result is quite consistent with data obtained by Hsu et al. [81] in their experiments on Sprague-Dawley rats that were subcutaneously exposed to a suspension containing MMT nano-plates.

V.V. Smirnova et al. [82] performed their experiments on male rats that were exposed to non-modified hydrophilic NC "Nanoclay Nanomer PGV" via a stomach tube for 28 days in a dose equal to 1 or $100 \mathrm{mg} / \mathrm{kg}$ of body weight. A lot of biochemical and hematologic parameters were then analyzed and the authors didn't reveal any changes in animals from the test group that could be considered unfavorable. Moreover, exposure to NC had certain effects indicating that antioxidant protection system became more active (diene conjugates contents in plasma went down and glutathione peroxidase became more active). Clay consumption didn't stimulate liver cells apoptosis or make intestinal walls more penetrable for macromolecules.

There was an experimental model that involved inducing hypercreatinemia in mice; montmorrilonite applied within it reduced creatinine contents in blood serum and accelerated its excretion from the intestines. Bentonite consumed by animals with renal failure made for urea diffusion out of blood vessels into the intestines and inhibited its absorption there [40]. Mice suffering from hyperthyrosis were given montmorrilonite and it reduced thyroxine and triiodothyronine contents, made for longer sleep, increased tolerance to hypoxia and reduced spontaneous motor activity [40].

Some researchers argue that absence of toxic effects produced by NCs is probably due to them being practically not biologically available under enteral introduction [80]. However, Baek et al. [45], although they didn't observe any toxic effects produced by MMT in a dose up to $1,000 \mathrm{mg} / \mathrm{kg}$ of body weight, still reported that clay minerals could be absorbed in a body during 2 hours with certain marker elements (silicon and aluminum) accumulating in specific organs. Mascolo et al. [74] detected an increasing accumulation of NCs marker elements in rats' urine and tissues, and the organs where 
they accumulated were distributed as per their quantities given in the descending order in the following way: kidneys $>$ liver $>$ heart $>$ brain. Reichardt et al. [83] showed that kaolinite could dissociate into the intestine lumen and escaping aluminum ions could be absorbed. Particles of organically modified Cloisite 30B nanoclay can be absorbed by epithelium cells in rats' esophagus [66]. However, Sharma et al. [80] didn't reveal any aluminum accumulation in the liver and kidneys of rats that were exposed to modified Cloisite 30B nanoclay via gavage in a dose equal to $1,000 \mathrm{mg} / \mathrm{kg}$ of body weight. EFSA experts [76] believe that bentonite and sepiolite are not absorbed in the gastrointestinal tract in any significant quantities.

Organic NC modifiers that can be dissociated from MMT both within a product and after being introduced into a body have their own toxic effects. In particular, Melin et al. [84] determined that quaternary ammonium bases caused grave disorders in reproductive health of mice. There was an experiment performed on rats; they were intragastrically exposed to didecyldimethyl-ammonium saccharinate via gavage in a dose equal to $2,000 \mathrm{mg} / \mathrm{kg}$ of body weight; the exposure resulted in death of all the experimental animals [54].

Only three research works focused on assessing clay nanocomposites toxicity. Thus, the authors of [64] indicated that NC composites didn't produce and toxic effects in vivo and were highly biologically compatible with polyurethane and chitosan. MMT nanocomposites / chitosan had more significant biological compatibility in vivo than pure chitosan [81]. Maisanaba et al. [85] exposed rats to substances that were extracted from a composite containing organically modified NC and poly-L-lactite and turned into a model drink; they didn't reveal any histopathologic or biochemical signs of toxicity.

Interaction with chemical toxicants. There are data in literature that allow assuming nanoclays being able to reduce toxicity of chemical toxicants when they are introduced together with them as the former can act as enterosorbents. Authors of some early works $[35,86]$ reported that it was quite efficient to add non-modified clays into forage for agricultural animals (chicken or pigs) in doses equal to $0.1-0.5 \%$ of the overall ration in order to prevent adverse effects produced by aflatoxins from group B that could be found in forage. Simultaneously it was shown that NCs in the mentioned doses didn't deteriorate biological availability of vitamins $\mathrm{B}_{2}$, and $\mathrm{A}$, phosphor, and manganese although there was a slight decrease in biological availability of zinc when the dose reached $1 \%$ (and it was higher than a recommended preventive one). Detoxication became especially efficient in case of aflatoxicosis when NCs were combined with such antioxidants as selenium, methionine, and vita$\min \mathrm{E}$.

Afriyie-Gyawu et al. [39] examined clinical materials taken in regions that were endemic in terms of aflatoxicosis in people. They revealed that it was quite efficient to use NC NovaSil as an enterosorbent and it didn't result in any risks related to vitamins $\mathrm{A}$ and $\mathrm{E}$ and mineral substances becoming less biologically available. Data obtained from the work by Abdel-Wahhab et al. [34] indicate that organically modified NC is able to absorb aflatoxins, fumonizine, and zearalenone.

El-Nekeety et al. [87] exposed Sprague Dawley rats to fumonizine $\mathrm{B}_{1}$ and/or zearalenone for 3 weeks; reference groups in their experiment were given only usual food or food with added MMT in a quantity equal to $0.5 \%$ of the overall provided food. After that the authors determined nitrogenous and lipid metabolism in blood plasma, LP products in the liver and kidneys, antioxidant enzymes activity, levels of carcinoembryonic antigen (CEA), alphafetoprotein and IL-6, and morphological parameters of the liver and kidneys. All the determined parameters indicated that MMT produced favorable therapeutic effects. There were no signs of toxic effects on animals that were given only MMT in the above-mentioned dose.

Therefore, high activity of NCs as enterosorbents for various toxic substances provides certain opportunities for using NCs in treating and preventing various intoxications both among people and animals. It creates additional exposure to both native and modified NCs. 
Antimicrobial activity. Some native clays were used to treat wounds in ancient times, long before their antimicrobial properties became known to medical science [88]. Antimicrobial effects produced by clays can occur due to both physical interactions with microbe cells and emissions of various chemical components. Physical antimicrobial effects are presumably determined by bacteria sticking to clay particles and, as a result, microorganisms fail to absorb necessary nutrients, they discharge metabolites, and their cellular walls are broken (Ferris et al., 1987, cited as per [5]). Wherein this clays rather produce bacteriostatic effects and not bactericidal ones [89].

Antimicrobial effects produced by NCs can be related to their ability to cause dysbiotic disorders in case they are introduced orally. Thus, Smirnova V.V. et al. [82] exposed Wistar rats to non-modified MMT and revealed lowering functional activity of symbiotic bifidobacteria in exposed animals together with a substantial (by 3 times) growth of yeast flora in the caecum.

When assessing probable chemical antibacterial effects produced by NCs, one should bear in mind that though aluminosilicate particles are poorly soluble in water, they can still release ions of metals (in particular aluminum or iron) in a biological medium where organic molecules are present; these released ions are able to produce antimicrobial effects [88]. Wang et al. [90] revealed antimicrobial effects produced on $S$. aureus and $E$. coli by exfoliated NCs and their forms modified with cationactive, anion-active and non-ionogenic SAS, as well as by nanocomposites with polyurethane.

Composite films based on Salvia macrosiphon sage seeds gluten and organicallymodified Cloisite 15A nanoclay demonstrated their antimicrobial properties regarding E.coli and S.aureus in test on agar [91]. A composite formed from negatively charged bentonite $\mathrm{NC}$ layers and monomolecular chitosan layers turned out to have antimicrobial effects on Pseudomonas syringe $p v$. tomato bacteria and Fusarium solani f. sp. Eumartii mold fungus that caused agricultural products spoilage [92]. It is assumed that such nanocomposites can also be so called "elicitors", that is, substances that non-specifically increase plants resistance to pests and pathogens.

Antimicrobial effects produced by clay minerals became widely used in clinical practices. Thus, patients suffering from diarrhea of various etiologies (viral infection, food allergies, spastic colitis, mucus colitis, and food poisoning) were given bentonite orally and it resulted in favorable clinical effects in $97 \%$ cases [93]. "Diosmectite" adsorbent that consists of natural aluminosilicate-magnesium clay is widely used in clinical practices to treat diarrhea and irritable bowels syndrome. The medication was shown to normalize stool due to its ability to absorb toxins, bacteria, and viruses and to enhance barriers created by the intestine mucosa thus reducing inflammation and penetration of luminal antigens through mucus layers. It also prevented adsorption of bacteria, enterotoxins, viruses, and other potentially diarrhea-inducing substances on cell membranes [94]. "Diosmectite" is also recommended to prevent negative side effects produced by radiation and chemical therapy as well as to treat acquired immunodeficiency syndrome involving chronic diarrhea [95]. When bentonite was prescribed to patients in a dose equal to $3 \mathrm{~g} /$ day for 8 weeks, it resulted in less apparent signs of irritable bowels syndrome against placebo [40].

Clinical research also revealed probable side effects produced by clay-based medications. Diosmectine (smecta) caused constipations, though in rare cases, and the effect was eliminated after a dose had been adjusted; sometimes (better to say, rather rarely) there were allergic reactions (nettle-rash, rash, itch, and Quincke's edema). Clays as enterosorbents have certain contraindications such as bowel obstruction, fructose intolerance, impaired glucose and galactose absorption, invertase-isomaltase insufficiency [95].

Therefore, plenty of data on antimicrobial effects produced by NCs and their composites not only substantiate their use in producing medical appliances and medications but also provide better insight into a probability that biological effects produced by NCs become 
obvious due to their interaction with intestinal microbiocenosis components under oral introduction into a body.

Migration form packing materials. A most significant role in assessing probable health risks caused by NCs belongs to determining quantities in which these nanomaterials and their organic modifiers migrate from packing materials $[96,97]$. We should note that contradictory results have been obtained in researching the issue. Schmidt et al. [98] didn't reveal any clay migration from poly-L-lactite in $95 \%$ ethanol within detection limits; and Bott et al. [99] also didn't detect any laponite migrating from low-density polyethylene into SAS solution. $\mathrm{Xia}$ et al. [100] detected only trace clay quantities $(3-6 \mu \mathrm{g} / \mathrm{l})$ migrating from polypropylene and polyamide films into ethanol. According to theoretical calculations made by Simon et al. [101], particles with their diameter exceeding $1 \mathrm{~nm}$ should not at all migrate from polymer phases due to their significant viscosity. However it is not the case with particles that are located on an interphase surface or close to it as well as with a situation when a polymer is being destroyed. Probably it was the reason for Avella et al. [19] to determine an increased concentration of silicon in vegetables that contacted a nanocomposite. However, it is rather difficult to interpret these data as a packing material used in that work was biologically degradable. Farhoodi et al. [-102] revealed that aluminum and silicon could migrate from PET bottles in acid medium under 25 and $45^{\circ} \mathrm{C}$. Other researchers showed that both aluminum and silicon could migrate from nanocomposites into water and water-ethanol media [103].

Echegoyen et al. [96] examined how aluminum migrated from containers consisting of two various polyethylene composites with organically modified NCs. All the tests were performed according to the EU Regulation $10 / 2011 /$ EU that involved using $10 \%$ ethanol and $3 \%$ acetic acid as model media under $70{ }^{\circ} \mathrm{C}$ for 2 hours or under $40{ }^{\circ} \mathrm{C}$ for 10 days. Under given conditions, Al migrated from samples in quantities varying from 2 to $51 \mathrm{ng}$ from $1 \mathrm{~cm}^{2}$ of their surface; the authors applied electronic microscopy and it allowed them to detect clay nano-plates in the model media. Their structure was additionally confirmed via energy dispersive spectroscopy. Xia et al. [100] examined migration of clay particles, $\mathrm{Si}$, $\mathrm{Al}$, and organic modifiers (quaternary ammonium bases) from polypropylene (PP) composites and polyamide 6 (PA6) with organically modified MMT into ethanol under $70{ }^{\circ} \mathrm{C}$. It was shown that more clay particles migrated from PP films than from PA6 ones $(0.15$ and $0.10 \mathrm{mg} / \mathrm{l}$ respectively); it was probably due to weaker interaction between organically modified NC and the first polymer. Modifiers migrated in ethanol in quantities being equal to $3.5 \mathrm{mg} / 1$ for PP films and $16.2 \mathrm{mg} / 1$ for PA6 ones. Treatment with ethanol also led to changes in nanocomposite ultra-structure. Aluminum migration from polyethylene nanocomposite into $3 \%$ acetic acid reached $5.16 \mu \mathrm{g} / \mathrm{cm}^{3}$ [96]; aluminum migration from PET-based nanocomposite into the same medium amounted to $0.34 \mathrm{mg} / \mathrm{kg}$, and silicon, $9.5 \mathrm{mg} / \mathrm{kg}$ [102]. Biopolymer films made from wheat gluten emitted up to $1 \mathrm{mg} / \mathrm{kg}$ aluminum and up to $4.5 \mathrm{mg} / \mathrm{kg}$ silicon into water, $3 \%$ acetic acid, $15 \%$ ethanol and vegetable oil [104].

NCs can migrate from packing materials not only under exposure to a medium that is characteristic for a food product but also due to weathering [105]. To assess this factor, model clay nanocomposites were treated with UV-radiation or ozone under $40{ }^{\circ} \mathrm{C}$. Physical and chemical properties of nanocomposites changed rather slowly during the first 130 hours and clay migration was also slow; after that, materials degraded rapidly and completely. Built-in nanoclays made an initial composite more stable and durable; however, they resulted in its faster degradation under exposure to UV-radiation. Nanoparticles that migrated from nanocomposites under weathering were $2-8 \mathrm{~nm}$ in size. Their concentration grew as treatment period got longer.

Therefore, contradictory data on migration of NCs and their components from packing materials indicate it is necessary to apply an individual approach to assessing their safety taking into account what structure an applied nanocomposite has, under what conditions it is 
applied, as well as properties of products that are packed in it.

Exposure and probable risks. People as a biological species have always been exposed to clays to a certain extent [106]; however, this exposure obviously has increased over the last two decades due to clay minerals being widely used in technology and medicine. Inhalation exposure accounts for the biggest part of the total one; intragastric and subcutaneous exposure follows [107, 108].

Occupational inhalation exposure usually occurs predominantly when minerals are extracted, in agriculture, and at aluminum-producing enterprises [5, 109]. This review doesn't include profound consideration of such exposure.

Data on oral exposure of people to MMT, kaolinite, and other clays are rather contradictory [4]. When clays are introduced into polymer materials, it can result to spontaneous exposure to them and it requires assessing migration of both microparticles and nano-structured clays from packing materials into food products [41]. Besides, NCs can penetrate the environment in considerable quantities during a product life cycle, for example, when wasted packaging and packing materials are incinerated at combustion plants [110]. Food additives and medications are other significant sources of oral exposure to clays in developed countries [111, 112]. Here we should mention bentonite, montmorrilonite, kaolinite, and palygorskite that are used as antacids and antidiarrhea medications [113]. Some clays are applied to prevent mycotoxicosis and aflatoxicosis in people in regions where endemic risks as per these health disorders are rather high $[39,114]$.

Bearing probable risks analysis in mind, we think that the most significant task here is to examine exposure of people to aluminosilicate food additives as they can be result in toxic aluminum being introduced into a human body. As per EFSA assessment, five aluminum-containing food additives, between them four should be treated as clays (acid sodium aluminophosphate E541; sodium aluminosilicate E554: potassium aluminosilicate E556; aluminosilicate-kaolin E559), are consumed by people from various age groups in quantities, recalculated as per aluminum, varying from 2.3 to $76.9 \mathrm{mg} / \mathrm{kg}$ per week on average for the whole population and from 7.4 to $145.9 \mathrm{mg} / \mathrm{kg}$ per week on average for $95 \%$ population depending on a scenario [1]. According to an alternative scenario assuming that food products with aluminum-containing food additives in their structure are consumed in greater quantities, average consumption amounted to $18.6-156.2 \mathrm{mg} / \mathrm{kg}$ of body weight per week; consumption for a $95 \%$ population sampling amounted to $5.3-286.8 \mathrm{mg} / \mathrm{kg}$ of body weight per week [115]. Therefore, aluminum that is contained in food additives is consumed by people from various age groups in quantities being considerably higher than its tolerable weekly intake from all the possible sources (TWI $=1 \mathrm{mg} / \mathrm{kg}$ of body weight) fixed by EFSA [, 116] as well as its provisional tolerable weekly intake (PTWI $=0-2.0 \mathrm{mg} / \mathrm{kg}$ of body weight) fixed by JECFA $[1,117]$.

Results obtained by other authors confirm that children, as a rule, consume aluminum with food in greater quantities per a unit of their body weight than adults though these data are a bit different from EFSA estimates. According to it, probable aluminum consumption by children aged 3-15 in France amounted to not less than $0.7 \mathrm{mg} / \mathrm{kg}$ of their body weight per week in $97.5 \%$. This quantity was equal to $2.3 \mathrm{mg} / \mathrm{kg}$ of body weight per week for pre-school children aged 1.5-4.5. In Great Britain in 1988 children aged 4-18 consumed aluminum in a quantity equal to $1.7 \mathrm{mg} / \mathrm{kg}$ of body weight. In Germany $10 \%$ of children aged 5-8 consumed aluminum with food in a quantity being higher than 0.38 $\mathrm{mg} / \mathrm{kg}$ of body weight per week. Potential consumption of aluminum contained in food products for infants by children aged $0-3,4-6,7-9$, and 10-12 months amounts respectively to 0.1 , $0.2,0.43$, and $0.78 \mathrm{mg} / \mathrm{kg}$ of body weight per week $[115,117]$. Research performed in China allowed revealing that average aluminum consumption by children in Shenzhen amounted to $3.272 \mathrm{mg} / \mathrm{kg}$ of body weight per week which was even higher than PTWI $=2 \mathrm{mg} / \mathrm{kg}$ of body weight per week fixed for adults [118]. 
According to [119] aluminum contents in various products for children aged 0-12 months varied from $224 \mu \mathrm{g} / 1$ per day to $592 \mu \mathrm{g} / \mathrm{l}$. Taking into account maximum recommended quantities in which these products can be consumed, aluminum consumption become unacceptably high for children older than 6 months.

There was a piece of research accomplished in Spain; it revealed that milk-based formulas for babies contained aluminum in quantities equal to $0.24-0.69 \mathrm{mg} / \mathrm{l}$, and soyabased ones, $0.93 \mathrm{mg} / 1$ [120]. The obtained data gave grounds for additional assessment of aluminum consumption with such products and it amounted to $0.2-0.6 \mathrm{mg} / \mathrm{kg}$ of body weight per week for 3-mointh old children in case milk-based food products were used, and $0.75 \mathrm{mg} / \mathrm{kg}$ of body weight per week for soyabased products. Should these products be consumed in significant quantities, aluminum consumption grew to $0.3-0.9 \mathrm{mg} / \mathrm{kg}$ of body weight per week and $1.1 \mathrm{mg} / \mathrm{kg}$ of body weight accordingly [121]. These data on increased aluminum contents in food products for babies (milk products, biscuits, dried cereals, desserts, fish, fruit purees, mea, macaroni, crackers, and vegetables) were confirmed by numerous research works [113, 122, 123].

We should note that aluminum-containing food additives are not included into the list of those that are permitted to be applied in products for children in conformity with the CU TR 029/2012 "Requirements to safety of additives to food, flavoring agents, and technological auxiliaries", Codex Standard 192-1995 "General Standard for Food Additives" approved by Codex Alimentarius, EU Regulation No. 1333/2008 regarding use of food additives. Besides, EU Regulation No, 1333/2008 strictly forbids using aluminum-containing food additives in ingredients for children nutrition. Nevertheless, as analytic research indicates, aluminum is detected in food products for children; it can occur there due to "transition" from food raw materials (for example, from powdered milk) as well as due to migration from package and packing materials.

Available data on aluminum toxicity and quantities in which the element was consumed with food products gave grounds for excluding potassium aluminosilicate E555 and bentonite E 558 from the list of food additives given in the Codex Standard 192-1995 "General Standard for Food Additives". However, an issue related to aluminum consumption with food additives probably exceeding maximum permissible levels still remains open. Therefore, experts from the RF proposed discussing the necessity to reconsider use of aluminum-containing food additives that were permitted for use in food industry at the 46 session of the FAO-WHO Experts Committee (CCFA46) held in Hong Cong on March 17-21 2014. CCFA46 voted for the proposal [124].

The last version of The EU Regulation No. 1333/2008 that was edited in 2019 excluded several types of clays from the list of food additives permitted for use in food industry; excluded clays were sodium aluminosilicate E554, potassium aluminosilicate E555, calcium aluminosilicate E556, bentonite E558, and aluminosilicate (Kaolin) E559 [125, 126].

Experts assessed aluminum consumption with nutrition by RF population and revealed that aluminum was consumed by all age groups in quantities substantially exceeding maximum permissible weekly levels that were equal to 0-2.0 mg/kg of body weight; aluminum consumption was 2-8 times higher than maximum permissible levels at the minimum calculated consumption of aluminum-containing food additives, and 30-95 times higher at the maximum calculated one. Given that, it seemed well-grounded to exclude certain food additives from the list of those permitted for use in food industries; excluded food additives were sodium aluminosilicate (E554), potassium aluminosilicate (E555), calcium aluminosilicate (E556), bentonite (E558), and aluminosilicates (kaolin) (E559) ${ }^{2}$. However, according to a deci-

\footnotetext{
2 The draft decision by the EAEU Council. On making alterations No 2 into the Customs Union Technical Regulation "Requirements to safety of food additives, flavoring agents, and technological auxiliaries" (CU TR 029/2012). The Eurasian Economic Union. Available at: https://docs.eaeunion.org/pd/ru-ru/0103370/pd_17122018 (14.02.2020).
} 
sion made by the workgroup on making alterations into the Customs Union Technical Regulations "On Requirements to safety of additives to food, flavoring agents, and technological auxiliaries", only four out of five food additives were excluded from the list of those permitted for use in food industry, namely E555, E556, E558, and E559.

Conclusion. NCs are nanomaterials made of aluminosilicate layers (plates) or, in some cases, nanotubes and nano-disks. NCs structure, in particular nanometer-thick weakly bonded layers in them, their ion-exchanging and sorptive properties, as well as poor gas permeability provide opportunities for their wide use in industry, agriculture, and medicine. Production of composite package and packing materials usually involves using hydrophobic organically modified NCs.

People can be orally exposed to NC particles due to their migration from packing materials into food products and drinks; when NCs are applied in medicine as enterosorbents; when they are contained in food additives or occur in residual quantities of technological auxiliaries; due to spontaneous contamination of agricultural raw materials and products with clays. Numerous researches that involved using model in vitro systems revealed cytotoxic effects produced by NCs on various cells as well as their potential mutagenic effects on microorganisms. As a rule, organically modified NCs tended to have greater cytotoxicity than their non-modified analogues. Effects produced by NCs on cells became apparent through oxidant stress, depletion of reduced glutathione resources, breaks in cell ultrastructure (mitochondria swelling, changes in endoplasmic reticulum), proteome and metabolome shifts, cellular necrosis and lysis. NC toxicity can probably have a mechanism that involves generating reactive oxygen forms at interphase boundaries as well as membranetropic effects produced by cation-active SAS that migrated from organically modified clays. And here, as a rule, experts tend to neglect another potentially significant mechanism that involves migration of toxic aluminum ions from NCs. Effective NC concentration in dif- ferent in vitro systems varies from 0.001 to $1 \mathrm{mg} / \mathrm{ml}$; it is extremely doubtful that such NC concentration could occur in organs or tissues under systemic exposure (obviously, excluding cases when NC clays are accumulated in lung alveoli under chronic inhalation exposure).

Researches on NCs toxicity in vivo yielded some contradictory results. NCs didn't produce apparent acute toxic effects on rodents as it was indicated practically in each research work. Results obtained via sub-acute and subchronic experiments that lasted up to 196 and single clinical observations were not so unambiguous. As opposed to original NCs, their organic modifiers were highly toxic when introduced into animals in their free form; however, a possibility that they could migrate from organically modified clay in vivo or in vitro still remains disputable. Despite their low toxicity, NCs are apparently able to release such microelements as silicon and aluminum in vivo and these microelements are partially biologically available. Many NCs produce antimicrobial effects and it indicates that dysbiotic disorders can possibly result from their oral introduction.

Apart from toxic effects, NCs can also exert various non-toxic impacts on a body related to enterosorption. Such impacts include protection from adverse effects produced by aflatoxins and, probably, other chemical contaminants in food products. According to available data, orally introduced NCs don't exert any significant influence on provision with vitamins; however, in certain cases they are able to reduce provision with microelements (such as zinc).

There are still significant gaps in assessing NCs toxicity and related risks; they should be filled via experimenting. Thus, effects produced by NCs in systems in vivo are characterized within insufficient dose ranges and it doesn't allow assuming there are no effects that paradoxically occur not under exposure to high doses but to low ones (as it was repeatedly shown in experiments with carbon nanotubes). Not enough attention has been given to local effects produced by NCs in the gastrointestinal tract as per such parameters as morphological changes in intestine mucosa, micro- 
biocenosis, and cytokine production by lymphoid tissue in the intestines. Influence exerted by NCs on microelement state of a body hasn't been studied at all regarding a wide range of parameters (excluding such "marker" elements as silicon and aluminum).

Contribution made by NCs contained in packing materials into overall population exposure to toxic aluminum should be thoroughly assessed due to already hazardous situation resulting from clay minerals being introduced into a body with food additives. Assessment of aluminum consumption with food by RF population revealed it was necessary exclude potassium aluminosilicate
(E555), calcium aluminosilicate (E556), bentonite (E558), and aluminosilicates (kaolin) (E559) from the list of food additives permitted for use in food industry.

Funding. The research has been accomplished due to a grant provided for fulfilling a state task within the Program for fundamental scientific research (The Subjects approved on by the RF Ministry for Education and Science No. 0529-2019-0057 "Developing a system of food products quality and safety including food additives and alcohol drinks manufactured with biotechnologies").

Conflict of interests. The authors declare there is no any conflict of interests.

\section{References}

1. Bagryantseva O.V., ShatrovG.N., KhotimchenkoS.A., BessonovV.V., Arnautov O.V. Aluminium: Food-related health risk assessment of the consumers. Health Risk Analysis, 2016, no. 1, pp. 59-68. DOI: $10.21668 /$ health.risk/2016.1.07.eng

2. OnishchenkoG.G., TutelyanV.A. On concept of toxicological studies, methodology of risk assessment, metods of identification and quantity determining of nanomaterials. Voprosy pitaniya, 2007, vol. 76, no. 6, pp. 4-8. (in Russian).

3. Maynard A.D. Nanotechnology: assessing the risks. Nano today,2006, vol. 1, no. 2, pp. 22-33. DOI: $10.1016 / \mathrm{S} 1748-0132(06) 70045-7$

4. Bentonite, kaolin, and selected clay minerals: Environmental Health Criteria 231. Geneva, World Health Organization, 2005, pp. 1-158. Available at: https://www.who.int/ipcs/publications/ehc/ehc_231.pdf (22.08.2019).

5. Maisanaba S., Pichardo S., Puerto M., Gutiérrez-Praena D., Cameán A.M., Jos A. Tox-icological evaluation of clay minerals and derived nanocomposites: a review. Environ. Res., 2015, vol. 138, pp. 233-254. DOI:10.1016/j.envres.2014.12.024

6. Jordá-Beneyto M., Alonso J., Salas J., Gallur M., Aucejo S., Clegg F., Breen C. Processed biopolymer films filled with modified montmorillonite for food packaging applications. Proceedings of the Polymer Processing Society 24th Annual Meeting, PPS-24, June 15-19, 2008, Salerno (Italy), pp. 15-19.

7. Jordá- Beneyto M., Ortuño N., Devis A., Aucejo S., Puerto M., Gutiérrez-Praena D., Houtman J., Pichardo S., Maisanaba S., Jos A., Use of nanoclay platelets in food packaging materials: technical and cytotoxity approach. Food Addit. Contam. Part A Chem. Anal. Control. Expo. Risk. Assess, 2014, vol. 31, no. 3, pp. 354-364. DOI: 10.1080/19440049.2013.874045

8. Lai M., Kim J.K., Effects of epoxy treatment of organoclay on structure, thermo-mechanical and transport properties of poly(ethylene terephthalate-co-ethylene naphthalate)/organoclay nanocomposites. Polymer, 2005, vol. 46, pp. 4722-4734. DOI:10.1016/j.polymer.2005.03.062

9. Pal R., Murthy H.N.N., Rai K.S., Krishna M., Influence of organomodified nanoclay on the mechanical behavior of vinylester/glass nanocomposites. Int. J. Chem. Tech. Res., 2014, vol. 6, pp. 916-928.

10. Betega de Paiva L., Morales A.R., Valenzuela Díaz F.R., Organoclays: properties, preparation and applications. Appl. Clay. Sci., 2008, Vol. 42, pp. 8-24. DOI: 10.1016/j.clay.2008.02.006

11. Yu J., Baek M., Chung H.E., Choi S.J. Physicochemical properties affecting the potentia-lin vitro cytotoxicity of inorganic layered nanoparticles. Toxicol. Environ. Health. Sci., 2010, vol. 2, pp. 149-152.

12. Murray H.H., Traditional and new applications for kaolin, smectite, and palygorskite: a general overview. Appl. Clay. Sci., 2000, vol. 17, pp. 207-221. DOI: 10.1016/S0169-1317(00)00016-8

13. Bitinis N., Hernández M., Verdejo R., Kenn, J.M., López-Machado M.A. Recent advances in clay/polymer nanocomposites. Adv. Mater., 2011, vol. 23, pp. 5229-5236. 
14. Tayeb A.H., Tajvidi M. Sustainable barrier system via self-assembly of colloidal montmorillonite and cross-linking resins on nanocellulose interfaces. ACS Appl. Mater. Interfaces, 2019, vol.11, no. 1 , pp. 1604-1615. DOI: 10.1021/acsami.8b16659

15. De Azeredo H.M.C. Nanocomposites for food packaging applications. Food. Res. Int., 2009, vol. 42, no. 11, pp. 1240-1253. DOI:10.1016/j.foodres.2009.03.019

16. Duncan T.V. Applications of nanotechnology in food packaging and food safety: barrier materials, antimicrobials and sensors. J. Colloid. Interf. Sci., 2011, vol. 363, no. 1, pp. 1-24. DOI: 10.1016/j.jcis.2011.07.017

17. Hatzigrigoriou N.B., Pasparydes C.D. Nanotechnology in plastic food-contact materials. J. Appl. Polym. Sci., 2011, vol. 122, no. 6, pp. 3720-3729. DOI: 10.1002/app.34786

18. Hetzer M., De Kee D., Wood/polymer/nanoclay composites, environmentally friendly sustanaible technologies: a review. Chem. Eng. Res. Des., 2008, vol. 86, no. 10, pp. 1083-1093. DOI: $10.1016 /$ j.cherd.2008.05.003

19. Avella M., De Vlieger J.J., Errico M.E., Fischer S., Vacca P., Volpe M.G. Biodegradable starch/clay nanocomposite films for food packaging applications. Food Chem., 2005, vol. 93, no. 3, pp. 467-474. DOI:10.1016/j.foodchem.2004.10.024

20. Salarbashi D., Noghabi M.S., Bazzaz B.S.F., Shahabi-Ghahfarrokhi I., Jafari B., Ahmadi R. Eco-friendly soluble soybean polysaccharide/nanoclay $\mathrm{Na}+$ bionanocomposite: Properties and characterization. Carbohydrate Polymers, 2017, vol.169, pp. 524-532. DOI: 10.1016/j.carbpol.2017.04.011

21. Iamareerat B., Singh M., Sadiq M.B., Anal A.K. Reinforced cassava starch based edible film incorporated with essential oil and sodium bentonite nanoclay as food packaging material. J. Food Sci. Technol., 2018, vol. 55, no. 5, pp. 1953-1959. DOI: 10.1007/s13197-018-3100-7

22. Butnaru E., Stoleru E., Brebu M.A., Darie-Nita R.N., Bargan A., Vasile C. Chitosan-based bionanocomposite films prepared by emulsion technique for food preservation. Materials (Basel), 2019, vol. 12, no. 3, pp. E373. DOI: 10.3390/ma12030373

23. Beigzadeh Ghelejlu S., Esmaiili M., Almasi H. Characterization of chitosan-nanoclay bionanocomposite active films containing milk thistle extract. Int. J. Biol. Macromol., 2016, vol. 86, pp. 613-621. DOI: $10.1016 /$ j.ijbiomac.2016.02.012

24. Brody A.L. Nano and food packaging technologies converge. Food Technol., 2006, vol. 60, no. 3, pp. 92-94.

25. Ray S., Quek S.Y., Easteal A., Chen X.D. The potential use of polymer-clay nanocom-posites in food packaging. Int. J. Food Eng., 2006, vol. 2, no. 4, pp. 22-25. DOI: 10.2202/1556-3758.1149

26. Boelter J.F., Brandelli A. Innovative bionanocomposite films of edible proteins containing liposome-encapsulated nisin and halloysite nanoclay. Colloids Surf. B. Biointerfaces, 2016, vol. 145, pp. 740-747. DOI: 10.1016/j.colsurfb.2016.05.080

27. Meira S.M., Jardim A.I., Brandelli A. Adsorption of nisin and pediocin on nanoclays. Food Chem., 2015, vol. 188, pp. 161-169. DOI: 10.1016/j.foodchem.2015.04.136

28. Lagaron J.M. Higher barriers and better performance. Food Eng. Ingredients, 2006, vol. 31, no. 2, pp. 50-51.

29. Echegoyen Y. Nanodevelopments in food packaging and labelling applications. In: Rai M., Ribeiro C., Mattoso L., Duran N., eds. Nanotechnologies in Food and Agriculture. Switzerland, Springer, 2015, pp. 141-166.

30. Gokkurt T., Durmus A., Sariboga V., Oksuzomer M.A.F. Investigation of thermal, rheological, and physical properties of amorphous poly(ethylene terephthalate) / organoclay nanocomposite films. J. Appl. Polym. Sci., 2013, vol. 129, no. 5, pp. 2490-2501. DOI: 10.1002/app.38982

31. Rodrigues L.A., Figueiras A., Veiga F., de Freitas R.M.., Nunes L.C., da Silva Filho E.C., da Silva Leite C.M. The systems containing clays and clay minerals from modified drug release: a review. Colloids Surf. B Biointerfaces, 2013, vol. 103, pp. 642-651. DOI: 10.1016/j.colsurfb.2012.10.068

32. Akbari Alavijeh M., Sarvi M.N., Ramazani Afarani Z. Properties of adsorption of vitamin $\mathrm{B}_{12}$ on nanoclay as a versatile carrier. Food Chem., 2017, vol. 219, pp. 207-214. DOI: 10.1016/j.foodchem.2016.09.140

33. Ramesh A., Hasegawa H., Maki T., Ueda K. Adsorption of inorganic and organic arsenic from aqueous solutions by polymeric $\mathrm{Al} / \mathrm{Fe}$ modified montmorillonite. Separation and Purifica-tion Technol., 2007, vol. 56, pp. 90-100. DOI:10.1016/j.seppur.2007.01.025 
34. Abdel-Wahhab M.A., El-Nekeety A.A., Hathout A.S., Sabery B.A., Ibrahim M.I., Gado R.A., Zawrah M.F., Aly S.E. Preparation and characterization of organo-modified nano montmorillonite and evaluation of its ability to adsorb aflatoxins, fumonisins and zearalenone from aqueous solution. Nano Sci. Tech. Open Lib., 2015, vol. 1, no. 1, pp.27-34.

35. Harvey R.B., Kubena L.F., Elissalde M.H., Corrier D.E., Phillips T.D. Comparison of two hydrated sodium calcium aluminosilicates compounds to experimentally protect growing barrows from aflatoxicosis. J. Vet. Diagn. Invest., 1994, vol. 6, no. 1, pp. 88-92. DOI:10.1177/104063879400600115

36. Humer E., Kröger I., Neubauer V., Reisinger N., Zebeli Q. Supplementation of a clay mineralbased product modulates plasma metabolomic profile and liver enzymes in cattle fed grain-rich diets. Animal, 2019, vol. 13, no. 6, pp. 1214-1223. DOI: 10.1017/S1751731118002665

37. Abrahams P.W., Davies T.C., Solomon A.O., Trow A.J., Wragg J. Human geophagia, calabash chalk and undongo: mineral element nutritional implications. PLoS One, 2013, vol. 8, no. 1, pp. e53304. DOI:10.1371/journal.pone.005330

38. Tayie F.A., Koduah G., Mork S.A.pp. Geophagia clay soil as a source of mineral nutrients and toxicants. African J. Food Agric. Nutr. Develop., 2013, vol.13, no. 1, pp.8. DOI: 10.18697/ajfand.56.12580

39. Afriyie-Gyawu E., Wang Z., Ankrah N.A., Xu L., Johnson N.M., Tang L., Guan H., Huebner H.J., Jolly P.E., Ellis W.O., Taylor R., Brattin B., Ofori-Adjei D., Williams J.H., Wang J.S., Phillips T.D. NovaSil clay does not affect the concentrations of vitamins $\mathrm{A}$ and $\mathrm{E}$ and nutrient minerals in serum samples from Ghanaians at high risk for aflatoxicosis. Food Addit. Contam. Part A., 2008, vol. 25, pp. 872-884. DOI: $10.1080 / 02652030701854758$

40. Moosavi M. Bentonite clay as a natural remedy: a brief review. Iran J. Public Health, 2017, vol. 46, no. 9, pp. 1176-1183.

41. EFSA. European Food Safety Authority. Scientific opinion guidance on the risk assessment of the application of nanoscience and nanotechnologies in the food and feed chain. EFSA J., 2011, vol 9, no. 5, pp. 1-36. DOI:10.2903/j.efsa.2011.2156

42. Eisenbrand G., Pool-Zobel B., Baker V., Balls B.J., Blaauboer B.J., Boobis A., Carere A., Kevekordes S., Lhuguenot J.C., Pieters R., Kleiner J. Methods of in vitro toxicology. Food Chem. Toxicol., 2002, vol. 40, no. 2-3, pp. 193-236.

43. Murphy E.J., Roberts E., Horrocks L.A. Aluminum silicate toxicity in cell cultures. Neuroscience, 1993, vol. 55, no. 2, pp. 597-605.

44. Li P.R., Wei J.C., Chiu Y.F., Su H.L. Peng F.C., Lin J.J. Evaluation on cytotoxicity and genotoxicity of the exfoliated silicate nanoclay. ACS Appl. Mater. Interfaces, 2010, vol. 2, pp. 1608-1613. DOI: $10.1021 / \mathrm{am} 1001162$

45. Baek M., Lee J.-A., Choi S.-J. Toxicological effects of a cationic clay, montmorillonite in vitro and in vivo. Mol. Cell. Toxicol., 2012, vol. 8, no. 1, pp. 95-101. DOI: 10.1007/s13273-012-0012-x

46. Sharma A.K., Schmidt B., Frandsen H., Jacobsen N.R., Larsen E.H., Binderup M.L. Ge-notoxicity of unmodified and organo-modified montmorillonite. Mutation Res., 2010, vol. 700, no. 1-2, pp. 18-25. DOI: $10.1016 /$ j.mrgentox.2010.04.021

47. Gao N., Keane M.J., Ong T., Wallace W.E. Effects of simulated pulmonary surfactant on the cytotoxicity and DNA-damaging activity of respirable quartz and kaolin. J. Toxicol. Environ. Health A., 2000, vol. 60, no. 3, pp.153-167.

48. Verma N.K., Moore E., Blau W., Volkov Y., Babu P.R., Cytotoxicity evaluation of na-noclays in human epithelial cell line A549 using high content screening and real-time impedance analysis. J. Nanopart. Res., 2012, vol. 14, no. 9, pp. 1137-1148. DOI: 10.1007/s11051-012-1137-5.

49. Vergaro V., Abdullayev E., Lvov Y.M., Zeitoun A., Cingolani R., Rinaldi R., Leporatti S. Cytocompatibility and uptake of halloysite clay nanotubes. Biomacromolecules, 2010, vol. 11, no. 3, pp. 820-826. DOI: $10.1021 / \mathrm{bm} 9014446$

50. Lai X., Agarwal M., Lvov Y.M., Pachpande C., Varahramyan K., Witzmann F.A. Proteomic profiling of halloysite clay nanotube exposure in intestinal cell co-culture. J. Appl. Toxicol., 2013, vol. 33, no. 11, pp. 1316-1329. DOI: 10.1002/jat.2858

51. Rawat K., Agarwal S., Tyagi A., Verma A.K., Bohidar H.B. Aspect ratio dependent cytotoxicity and antimicrobial properties of nanoclay. Appl. Biochem. Biotechnol., 2014, vol.174, no. 3, pp.936-944. DOI: $10.1007 / \mathrm{s} 12010-014-0983-2$ 
52. Lordan S., Kennedy J.E., Higginbotham C.L. Cytotoxic effects induced by unmodified and organically modified nanoclays in the human hepatic HepG2 cell line. J. Appl. Toxicol., 2011, vol. 31, no. 1 , pp. 27-35. DOI: $10.1002 /$ jat.1564

53. Janer G., Fernández-Rosas E., Mas del Molino E., González-Gálvez D., Vilar G., LópezIglesias C., Ermini V., Vázquez-Campos S. In vitro toxicity of functionalised nanoclays is mainly driven by the presence of organic modifiers. Nanotoxicology, 2014, vol. 8, no. 3, pp. 279-294. DOI: $10.3109 / 17435390.2013 .776123$

54. Jodynis-Liebert J., Nowicki M., Murias M., Adamska T., Ewertowska M., Kujawska M., Piotrowska H., Konwerska A., Ostalska-Nowicka D., Pernak J. Cytotoxicity, acute and sub-chronic toxicity of ionic liquid, didecyldimethylammonium saccharinate in rats. Regul. Toxicol. Pharmacol., 2010, vol. 57, no. 2-3, pp. 266-273. DOI: 10.1016/j.yrtph.2010.03.006

55. Maisanaba S., Puerto M., Pichardo S., Jordá M., Moreno F.J., Aucejo S., Jos Á. In vitro toxicological assessment of clays for their use in food packaging applications. Food Chem. Toxicol., 2013, vol. 57, no. 6, pp. 266-275. DOI: 10.1016/j.fct.2013.03.043

56. Houtman J., Maisanaba S., Puerto M., Gutiérrez-Praena D., Jordá M., Aucejo S., Jos A. Toxicity assessment of organomodified clays used in food contact materials on human target cell lines. Appl. Clay Sci., 2014, vol. 90, pp. 150-158. DOI: 10.1016/j.clay.2014.01.009

57. Maisanaba S., Pichardo S., Jordá-Beneyto M., Aucejo S., Cameán A.M., Jos A. Cytotoxicity and mutagenicity studies on migration extracts from nanocomposites with potential use in food packaging. Food Chem. Toxicol., 2014, vol. 66, pp. 366 -372. DOI: 10.1016/j.fct.2014.02.011

58. Maisanaba S., Prieto A., Pichardo S., Jordá-Beneyto M., Aucejo S., Jos A. Cytotoxicity and mutagenicity assessment of organomodified clays potentially used in food packaging. Toxicol. in vitro, 2015, vol. 29, no. 6, pp. 1222-1230. DOI: 10.1016/j.tiv.2015.03.010

59. Zhang M., Li X., Lu Y., Fang X., Chen Q., Xing M., He J. Studying the genotoxic effects induced by two kinds of bentonite particles on human B lymphoblast cells in vitro. Mutation Res., 2011, vol. 720, pp. 62-66. DOI:10.1016/j.mrgentox.2010.12.009

60. Zhang M., Lu Y., Li X., Chen Q., Lu L., Xing M., Zou H., He J.Studying the cytotoxicity and oxidative stress induced by two kinds of bentonite particles on human B lymphoblast cells in vitro. Chem. Biol. Interact., 2010, vol. 183, no. 3, pp. 390-396. DOI: 10.1016/j.cbi.2009.11.023

61. Han H.K., Lee Y.C., Lee M.Y., Patil A.J., Shin H.J. Magnesium and calcium organophyllosilicates: synthesis and in vitro cytotoxicity study. ACS Appl. Mater. Interfaces, 2011, vol. 3, no. 7, pp. 2564-2572. DOI: $10.1021 / \mathrm{am} 200406 \mathrm{k}$

62. Liu Q., Liu Y., Xiang S., Mo X., Su S., Zhang J. Apoptosis and cytotoxicity of oligo(styreneco-acrylonitrile)-modified montmorillonite. Appl. Clay Sci., 2011, vol. 51, pp. 214-219. DOI: 10.1016/j.clay.2010.11.019

63. Liu M., Zhang Y., Wu C., Xiong S., Zhou C. Chitosan/halloysite nanotubes bionanocomposites: structure, mechanical properties and biocompatibility. Int. J. Biol. Macromol., 2012, vol. 51, no. 4, pp. 566-575. DOI: 10.1016/j.ijbiomac.2012.06.022

64. Zia K.M., Zuber M., Barikani M., Hussain R., Jamil T., Anjum S. Cytotoxicity and mechanical behavior of chitin-bentonite clay based polyurethane bio-nanocomposites. Int J. Biol. Macromol., 2011, vol. 49, no. 5, pp. 1131-1136. DOI: 10.1016/j.ijbiomac.2011.09.010

65. Kevadiya B.D., Chettiar S.S., Rajkumar S., Bajaj H.C., Gosai K.A., Brahmbhatt H. Evaluation of clay/poly (L-lactide) microcomposites as anticancer drug 6-mercaptopurine reservoir through in vitro cytotoxicity, oxidative stress markers and in vivo pharmacokinetics. Colloids Surf. B Biointerfaces, 2013, vol. 112, pp. 400-407. DOI: 10.1016/j.colsurfb.2013.07.008

66. Salarbashi D., Tafaghodi M., Bazzaz B.S.F., Mohammad Aboutorabzade Birjand S., Ba-zeli J. Characterization of a green nanocomposite prepared from soluble soy bean polysaccharide/Cloisite 30B and evaluation of its toxicity. Int. J. Biol. Macromol., 2018, vol.120, pt A, pp. 109-118. DOI: 10.1016/j.ijbiomac.2018.07.183.

67. Wagner A., Eldawud R., White A., Agarwal S., Stueckle T.A., Sierros K.A., Rojanasakul Y., Gupta R.K., Dinu C.Z. Toxicity evaluations of nanoclays and thermally degraded byproducts through spectroscopical and microscopical approaches. Biochim. Biophys. Acta, 2017, vol. 1861, no. 1, pt A, pp. 3406-3415. DOI: 10.1016/j.bbagen.2016.09.003 
68. Wagner A., White A.P., Stueckle T.A., Banerjee D., Sierros K.A., Rojanasakul Y., Agarwal S., Gupta R.K., Dinu C.Z. Early assessment and correlations of nanoclay's toxicity to their physical and chemical properties. ACS Appl. Mater. Interfaces, 2017, vol. 9, no. 37, pp. 32323-32335. DOI:10.1021/acsami.7b06657

69. Murphy E.J., Roberts E., Anderson D.K., Horrocks L.A. Cytotoxicity of aluminium silicates in primary neuronal cultures. Neuroscience, 1993, vol. 57, pp. 483-490.

70. Elmore A.R. Final report on the safety assessment of aluminum silicate, calcium silicate, magnesium aluminum silicate, magnesium silicate, magnesium trisilicate, sodium magnesium silicate, zirconium silicate, attapulgite, bentonite, Fuller's earth, hectorite, kaolin, lithium magnesium silicate, lithium magnesium sodium silicate, montmorillonite, pyrophyllite, and zeolite. Int. J. Toxicol., 2003, vol. 22, suppl. 1, pp. 37-102.

71. Slamova R., Trckova M., Vondruskova H., Zraly Z., Pavlik I. Clay minerals in animal nutrition. Appl. Clay Sci., 2011, vol. 51, no. 4, pp. 395-398. DOI: 10.1016/j.clay.2011.01.005

72. Wilson M.J. Clay mineralogical and related characteristics of geophagic materials. J. Chem. Ecol., 2003, vol. 29, no. 7, pp. 1525-1547.

73. Lee Y.H., Kuo T.F., Chen B.Y., Feng Y.K., Wen Y.R., Lin W.C., Lin F.H. Toxicity assessment of montmorillonite as a drug carrier for pharmaceutical applications: yeast and rats model. Biomed. Eng. Appl. Basis Commun., 2005, vol. 17, pp. 72-78. DOI: 10.4015/S1016237205000111

74. Mascolo N., Summa V., Tateo F. In vivo experimental data on the mobility of hazardous chemical elements from clays. Appl. Clay Sci., 2004, vol. 25, no. 1-2, pp. 23-28. DOI: 10.1016/j.clay.2003.07.001

75. Afriyie-Gyawu E., Mackie J., Dash B., Wiles M., Taylor J., Huebner H., Tang L., Guan H., Wang J.S., Phillips T. Chronic toxicological evaluation of dietary NovaSil clay in Sprague-Dawley rats. Food Addit. Contam., 2005, vol. 22, no. 3. pp. 259-269. DOI: 10.1080/02652030500110758

76. EFSA. European Food Safety Authority. Scientific opinion on the safety and efficacy of a preparation of bentonite and sepiolite (Toxfin Dry) as feed additive for all species. EFSA J., 2013, vol.11, no. 4, pp. 1-21. DOI: 10.2903/j.efsa.2013.3179

77. Maisanaba S., Gutiérrez-Praena D., Puerto M., Moyano R., Blanco A., Jordá M., Cameán A.M., Aucejo S., Jos A. Effects of the subchronic exposure to organomodified clay for food packaging applications on Wistar rats. Appl. Clay. Sci., 2014, vol. 95, pp. 37-40. DOI: 10.1016/j.clay.2014.04.006

78. Maisanaba S., Puerto M., Gutiérrez-Praena D., Llana-Ruíz-Cabello M., Pichardo S., Mate A., Jordá-Beneyto M., Cameán A.M., Aucejo S., Jos A. In vivo evaluation of activities and expression of antioxidant enzymes in Wistar rats exposed for 90 days to a modified clay. J. Toxicol. Environ. Health A., 2014, vol. 77, no. 8, pp. 456-466. DOI: 10.1080/15287394.2013.876696

79. Wiles M.W., Huebner H.J., Afriyie-Gyawu E., Taylor R.J., Bratton G.R., Phillips T.D. Toxicological evaluation and metal bioavailability in pregnant rats following exposure to clay minerals in the diet. J. Toxicol. Environ. Health A., 2004, vol. 67, no. 11, pp. 863-874. DOI: 10.1080/15287390490425777

80. Sharma A.K., Mortensen A., Schmidt B., Frandsen H., Hadrup N., Larsen E.H., Binderup M.L. In vivo study of genotoxic and inflammatory effects of the organo-modified Montmorillonite Cloisite 30B. Mutation Res., 2014, vol. 770, pp. 66-71. DOI: 10.1016/j.mrgentox.2014.04.023

81. Hsu S., Wang M., Lin J. Biocompatibility and antimicrobial evaluation of montmorillonite/chitosan nanacomposites. Appl. Clay Sci., 2012, vol. 56, pp. 53-62. DOI: 10.1016/j.clay.2011.09.016

82. Smirnova V.V., Tananova O.N., Shumakova A.A., Trushina E.N., Avren’yeva L.I., Bykova I.B., Minayeva L.P., Soto S.KH., Lashneva N.V., Gmoshinski I.V., Khotimchenko S.A. Toxicological and sanitary characterization of bentonite nanoclay. Gigiyena $i$ sanitariya, 2012, no. 3, pp.76-78. (in Russian).

83. Reichardt F., Oudart H., Ackermann A., Sabatier L., Lignot J., Habold C., Boos A., Ha-gege A., Liewig H.N. Clay complementation in rat diet: chronic effect of kaolinite on the intestinal lining. Comp. Biochem. Physiol. A Mol. Integr. Physiol., 2007, vol. 146, no. 4, pp. S186-S187. DOI: 10.1016/j.cbpa.2007.01.408

84. Melin V.E., Potineni H., Hunt P., Griswold J., Siems B., Were S.R., Hrubec T.C. Exposure to common quaternary ammonium disinfectants decreases fertility in mice. Reprod. Toxicol., 2014, vol. 50, pp. 163-170. DOI: 10.1016/j.reprotox.2014.07.071

85. Maisanaba S., Gutiérrez-Praena D., Puerto M., Llana-Ruiz-Cabello M., Pichardo S., Moyano R., Blanco A., Jordá-Beneyto M., Jos A. In vivo toxicity evaluation of the migration extract of an 
organomodified clay-poly(lactic) acid nanocomposite. J. Toxicol. Environ. Health A., 2014, vol. 77, no. 13, pp. 731-746. DOI: 10.1080/15287394.2014.890987

86. Phillips T.D. Dietary clay in the chemoprevention of aflatoxin-induced disease. Toxicol. Sci., 1999, vol. 52, suppl. 2, pp. 118-126. DOI: 10.1093/toxsci/52.suppl_1.118

87. El-Nekeety A.A., El-Kady A.A., Abdel-Wahhab K.G., Hassan N.S., Abdel-Wahhab M.A. Reduction of individual or combined toxicity of fumonisin B1 and zearalenone via dietary inclusion of organo-modified nano-montmorillonite in rats. Environ. Sci. Pollut. Res. Int., 2017, vol. 24, no. 25, pp. 20770-20783. DOI: 10.1007/s11356-017-9721-y

88. Williams L.B., Metge D.W., Eberl D.D., Harvey R.W., Turner A.G., Prapaipong P., PoretPeterson A.T. What makes a natural clay antibacterial? Environ. Sci. Technol., 2011, vol. 45, no. 8, pp.3768-3773. DOI: 10.1021/es1040688

89. Williams L.B., Haydel S.E. Evaluation of the medicinal use of clay minerals as antibac-terial agents. Int. Geol. Rev., 2010, vol. 52, no. 7-8, pp. 745-770. DOI: 10.1080/00206811003679737

90. Wang M.C., Lin J.J., Tseng H.J., Hsu S.H. Characterization, antimicrobial activities and biocompatibility of organically modified clays and their nanocomposites with polyurethane. Appl. Mater. Interfaces, 2012, vol. 4, no. 1, pp. 338-350. DOI: 10.1021/am2014103

91. Davachi S.M., Shekarabi A.S. Preparation and characterization of antibacterial, eco-friendly edible nanocomposite films containing Salvia macrosiphon and nanoclay. Int. J. Biol. Macromol., 2018, vol. 113, pp. 66-72. DOI: 10.1016/j.jibiomac.2018.02.106

92. Merino D., Mansilla A.Y., Casalongué C.A., Alvarez V.A. Preparation, characterization, and in vitro testing of nanoclay antimicrobial activities and elicitor capacity. J. Agric. Food Chem., 2018, vol. 66, no. 12, pp. 3101-3109. DOI: 10.1021/acs.jafc. 8 b00049

93. Lee K.J. Pharmacologic agents for chronic diarrhea. Intest. Res.,2015, vol. 13, pp. 306-312. DOI: $10.5217 /$ ir.2015.13.4.306

94. Chang F.-Y. Irritable bowel syndrome: The evolution of multi-dimensional looking and multidisciplinary treatments. World J. Gastroenterol., 2014, vol. 20, no. 10, pp. 2499-2514. DOI:10.3748/wjg.v20.i10.2499

95. Pérez-Gaxiola G., Cuello-García C.A., Florez I.D., Pérez-Pico V.M. Smectite for acute infectious diarrhoea in children. Cochrane Database of Systematic Reviews, 2018, Issue 4, Art. pp. CD011526. DOI: 10.1002/14651858.CD011526.pub2

96. Echegoyen Y., Rodríguez S., Nerín C. Nanoclay migration from food packaging materials. Food Addit. Contam. Part A, 2016, vol. 33, no. 3, pp. 530-539. DOI: 10.1080/19440049.2015.1136844

97. Xia Y., Rubino M., Auras R. Interaction of nanoclay-reinforced packaging nanocomposites with food simulants and compost environments. Adv. Food Nutr. Res., 2019, vol. 88, pp. 275-298. DOI: 10.1016/bs.afnr.2019.02.001

98. Schmidt B., Petersen J.H., Bender Koch C., Plackett D., Johansen N.R., Katiyar V., Larsen E.H. Combining asymmetrical flow field-flow fractionation with light scattering and induc-tively coupled plasma mass spectrometric detection for characterization of nanoclay used in biopolymer nanocomposites. Food Addit. Contam., 2009, vol. 26, no. 12, pp. 1619-1627. DOI: 10.1080/02652030903225740

99. Bott J., Franz R. Investigation into the potential migration of nanoparticles from laponitepolymer nanocomposites. Nanomaterials (Basel), 2018, vol. 8, no. 9, pp. E723. DOI:10.3390/ nano8090723.

100. Xia Y., Rubino M., Auras R. Release of nanoclay and surfactant from polymer-clay nanocomposites into a food simulant. Environ. Sci. Technol., 2014, vol. 48, no. 23, pp. 13617-13624. DOI:10.1021/es502622c.

101. Simon P., Chaudhry Q., Bakos D. Migration of engineered nanoparticles from polymer packaging to food - a physicochemical view. J. Food Nutr. Res., 2008, vol. 47, no. 3, pp. 105-113.

102. Farhoodi M., Mousavi S. M., Sotudeh-Gharebagh R., Emam-Djomeh Z., Oromiehie A. Migration of aluminum and silicon from PET/clay nanocomposite bottles into acidic food simulant. Packaging Technology and Science, 2013, vol. 27, no. 2, pp. 161-168. DOI:10.1002/pts.2017.

103. Diaz C.A., Xia Y., Rubino M., Auras R., Jayaraman K., Hotchkiss J. Fluorescent labeling and tracking of nanoclay. Nanoscale, 2013, vol. 5, no. 1, pp.164-168. DOI: 10.1039/c2nr32978f 
104. Mauricio-Iglesias M., Peyron S., Guillard V., Gontard N. Wheat gluten nanocomposite films as food-contact materials: Migration tests and impact of a novel food stabilization technology (high pressure). J. Appl. Polymer Sci., 2010, vol. 116, no. 5, pp. 2526-2535. DOI: 10.1002/app.31647

105. Han C., Zhao A., Varughese E., Sahle-Demessie E. Evaluating weathering of food pack-aging polyethylene-nanoclay composites: release of nanoparticles and their impacts. NanoIm-pact, 2018, vol. 9, pp. 61-71. DOI: 10.1016/j.impact.2017.10.005

106. López-Galindo A., Viseras C., Cerezo P. Compositional, technical and safety specifications of clays to be used as pharmaceutical and cosmetic products. Appl. Clay Sci., 2007, vol. 36, no. 1-3, pp. 51-63. DOI: 10.1016/j.clay.2006.06.016

107. Silvestre C., Duraccio D., Cimmino S. Food packaging based on polymer nanomaterials. Prog. Polym. Sci., 2011, vol. 36, no. 12, pp. 1766-1782. DOI:10.1016/j.progpolymsci. 2011.02.003

108. Zhao J., Castranova V. Toxicology of nanomaterials used in nanomedicine. J. Toxicol. Env. Health B., 2011, vol. 14, no. 8, pp. 593-632. DOI: 10.1080/10937404.2011.615113

109. Zhu H., Njuguna J. Nanolayered silicate/clay minerals uses and effects on health. Health and Environmental Safety of Nanomate-rials. In: JNjuguna,K.Pielichowski, H. Zhu, eds. The Netherlands Woodhead Publishing, Elsevier, 2014, pp. 133-146.

110. Wagner A., White A.P., Tang M.C., Agarwal S., Stueckle T.A., Rojanasakul Y., Gupta R.K., Dinu C.Z. Incineration of nanoclay composites leads to byproducts with reduced cellular reactivity. Sci. Rep., 2018, vol. 8, no. 1, pp.10709. DOI: 10.1038/s41598-018-28884-y

111. Carretero M.I. Clay minerals and their beneficial effects upon human health. A review. Appl. Clay Sci., 2002, vol. 21, no. 3-4, pp. 155-163. DOI:10.1016/S0169-1317(01)00085-0

112. Droy-Lefaix M.T., Tateo F. Clays and clay minerals as drugs. Handbook of Clay Science, vol. 1. In: F. Bergaya, B.KG.Theng, G. Lagaly, eds. The Netherlands,Elsevier, 2006, pp. 743-752.

113. Carretero M.I., Gomes C.S.F., Tateo T. Clays and human health. Handbook of Clay Science, vol. 1. In: F. Bergaya, B.K.GTheng, L. Lagaly, eds. The Netherlands, Elsevier, 2006, pp. 717-741.

114. Phillips T.D., Afriyie-Gyawu E., Williams J., Huebner H., Ankrah N.A., Ofori-Adjei D., Jolly P., Johnson N., Taylor J., Marroquin-Cardona A., Xu L., Tang L. Wang J.S. Reducing human exposure to aflatoxin through the use of clay: a review. Food Addit. Contam. A, 2008, vol. 25, no. 2, pp. 134-145. DOI: $10.1080 / 02652030701567467$

115. Aguilar F., Autrup H., Barlow S. et al. Safety of aluminium from dietary intake. Scientific Opinion of the Panel on Food Additives, Flavourings, Processing Aids and Food Contact Ma-terials (AFC). EFSA J., 2008, vol. 754, pp. 1-34. DOI: 10.2903/j.efsa.2008.754

116. EFSA. European Food Safety Authority. Dietary exposure to aluminium-containing food additives. Supporting Publications 2013:EN-411. 17 p. Available at:http:/www.efsa.europa.eu/en/supporting/pub/en$411(14.02 .2020)$.

117. Evaluation of certain food additives and contaminants: sixty-seventh report of the Joint FAO / WHO Expert Committee on Food Additives. WHO Technical Report, 2007. Series 940,pp.33-48. Available at: https://apps.who.int/iris/bitstream/handle/10665/43592/WHO_TRS_940_eng.pdf;jsessionid= 22993D369D427464DB04531CA7049498? sequence=1 (14.02.2020).

118. Aluminium in food. Risk Assessment. Studies Report No. 35. Chemical Hazard Evalua-tion. Centre for Food Safety Food and Environmental Hygiene Department. The Government of the Hong Kong Special Administrative Region, 2009. 45 p. Available at https://www.cfs.gov.hk/english/programme/programme_rafs/files/RA35_Aluminium_in_Food_e.pdf (14.02.2020).

119. Burrell S.-A.M, Exley C. There is (still) too much aluminium in infant formulas. BMC Pediatrics, 2010, no. 10, pp. 63-67. DOI: 10.1186/1471-2431-10-63

120. Navarro-Blasco I., Alvarez-Galindo J.I. Aluminum content of Spanish infant formula. Food Addit. Contam., 2003, vol. 20, no. 5, pp. 470-481. DOI: 10.1080/0265203031000098704

121. EMA. European Medicines Agency. Studies to evaluate the safety of residues of veterinary drugs in human food: general approach to establish a microbiological ADI. London, 2012. Available at:https:/www.ema.europa.eu/en/documents/scientific-guideline/vich-gl36r-studies-evaluate-safetyresidues-veterinary-drugs-human-food-general-approach-establish_en.pdf (14.02.2020).

122. Rondeau V., Jacqmin-Gadda H., Commenges D., Helmer C., Dartigues J.F. Aluminum and silica in drinking water and the risk of Alzheimer's disease or cognitive decline: findings from 15- 
year follow-up of the PAQUID cohort. Am. J. Epidemiol., 2009, vol. 169, no. 4, pp. 489-496. DOI: 10.1093/aje/kwn348

123. Poole R.L., Pieroni K.P., Gaskari S., Dixon T., Kerner J.A. Aluminum exposure in neonatal patients using the least contaminated parenteral nutrition solution products. Nutrients, 2012, vol. 4, no. 11 , pp. $1566-1574$. DOI: $10.3390 /$ nu4111566

124. Report of the forty-sixth session of the codex committee on food additives. Hong Kong, China 17-21 March 2014, REP14/FA, 116 pp. Available at: http://www.jhnfa.org/k149.pdf (14.02.2020).

125. Regulation (EU) No 1333/2008 of the European Parliament and of the Council of 16 December 2008 on food additives. Official Journal of the European Union, L 354/16.Available at:https://eurlex.europa.eu/legal-content/EN/TXT/

?uri $=$ celex\%3A32008R1333 (14.02.2020).

126. Commission regulation (EU) No 380/2012 of 3 May 2012 amending Annex II to Regulation (EC) No 1333/2008 of the European Parliament and of the Council as regards the conditions of use and the use levels for aluminium-containing food additives. Official Journal of the European Union, 2012, vol. 119, pp.14-38.

Gmoshinski I.V., Bagryantseva O.V., Arnautov O.V., Khotimchenko S.A. Nanoclays in food products: benefits and possible risks (literature review). Health Risk Analysis, 2020, no. 1, pp. 142-164. DOI: 10.21668/health.risk/2020.1.16.eng

Received: 17.02 .2019

Accepted: 18.03 .2020

Published: 30.03.2020 